\title{
Construction history of the aqueduct of Nicaea (Iznik, NW Turkey) and its on- fault deformation viewed from archaeological and geophysical investigations
}

\author{
Yacine BenJelloun ${ }^{1 *}$, Hélène DesSales ${ }^{2}$, Julia De SIGoYer ${ }^{1}$, Stéphane GARAMBoIs ${ }^{1}$, Mustafa ŞAHIN ${ }^{3}$ \\ ${ }^{1}$ Univ. Grenoble Alpes, Univ. Savoie Mont Blanc, CNRS, IRD, IFSTTAR, ISTerre, 38000 Grenoble, \\ France
}

${ }^{2}$ UMR 8546, Laboratoire AOROC, ENS, 75230 Paris, France

${ }^{3}$ Fen-Edebiyat Fakültesi, Arkeologi Bölümü, Uludag Üniversitesi, Bursa, Turkey

*Corresponding author ; Email : yacini@wanadoo.fr

\begin{abstract}
The aqueduct of Nicaea (modern Iznik, in northwestern Turkey) was studied for the first time using combined stratigraphical and geophysical methods. The analysis of the different materials and building techniques used allowed us to individualize more than forty stratigraphical units on the section investigated, using thirteen specific techniques. The comparison of certain masonries with analogous techniques visible in the defensive walls of the city and our stratigraphical interpretations led us to propose a chronology of the construction divided into nine phases. Some of these rebuildings seem linked to war and earthquake damage. The aqueduct was originally built in the first centuries $A D$ using a framework of terracottas and limestone rubble. Later on, two functional terracotta structures were added and the specus was extensively rebuilt. In a second period, the early facing was replaced by well-cut travertines. Significant rebuilding occurred around the $11^{\text {th }}$ century when the city went under attacks with the Turks. The last modifications date from the Lascarid period and are probably linked to the construction of a second defensive wall in the $13^{\text {th }}$ century, which cuts the western end of the aqueduct. Geophysical acquisitions on the eastern section of the aqueduct evidenced a vertical offset of the building located on an active normal fault unsuspected before. This kind of multidisciplinary approaches are powerful tools to study active tectonics and their impact on past societies.
\end{abstract}




\section{Introduction}

Located in the southeast of the Marmara Sea, the ancient city of Nicaea (modern Iznik) has been an important political and cultural centre in Asia Minor since the Hellenistic period (Fig. 1). In addition to this geopolitical importance, the history of the city is marked by several destructive earthquakes linked to an active strand of the North Anatolian fault system that passes $3 \mathrm{~km}$ south of Iznik. The city came under the rule of the Roman Republic in $72 \mathrm{BC}$ and has preserved several noticeable buildings from this period of time, among which a theatre, defensive walls and an aqueduct. While the walls have been the subject of several comprehensive studies (Foss, 1982, 1996; Foss and Winfield, 1986; Schneider and Karnapp, 1938), the aqueduct has never been studied in detail. Aqueducts were vital infrastructures in ancient cities and their study can therefore provide precious information. They were generally carefully maintained and rapidly repaired when damaged. Studying their construction history can thus help to document the evolution of the wealth and political stability of the city, as well as the occurrence of catastrophic events related to wars or natural hazards. Aqueducts are often several kilometers long, linear buildings, and their relatively simple structure makes them convenient to model, in order to simulate their behavior during seismic shaking for example (Volant et al., 2009). Certain aqueducts are even cross-cut by active fault segments and can be used to identify past earthquakes and derive the fault slip rate (Galli and Naso, 2009; Passchier et al., 2013; Sbeinati et al., 2010). When the water running in the aqueduct is charged with dissolved carbonates, sinter deposits tend to grow on the walls of the channel and can be analyzed as palaeoenvironmental archives (Passchier et al., 2016).

Most of the visible remains of this aqueduct extend in the east of Iznik from the Lefke Gate (Fig. 1b). As the ground level elevation increases eastward, the height of the aqueduct tends to decrease (Fig. 2). The recent excavations done around Lefke Gate have revealed that the base courses of the aqueduct were partly buried, and that the ground level was lower than today when the aqueduct was built. Close to the city gate, the channel of the aqueduct is enlarged on a few meters before finding its normal width again. After $600 \mathrm{~m}$, the aqueduct shows a significant change in its direction associated with a peculiar terracotta structure on its northern facing. It then follows a NW-SE orientation along Abdülvahap hill and present an underground section along the slope of a karstified carbonate massif on about $450 \mathrm{~m}$. This underground section is made visible by several pits dug by man. A few built remains are again visible on $100 \mathrm{~m}$ at the southern tip of the hill, along the road to Kaynarca. The total length of the aqueduct visible continuously on the field amounts to about $1.5 \mathrm{~km}$. It is likely that the sources used at the time were located in the karstic massif east of Iznik, in the vicinity of Dereköy village, $\sim 6 \mathrm{~km}$ east of Iznik (Fig. 1c). The aqueduct is built as a large wall, pierced by several arches. The wall is composed of two masonry facings with in between the "nucleus", a mixture of various materials and mortar. This wall supports the channel ("specus") of the aqueduct where the water used to run. The lateral walls of the specus are covered on the inside by a special, hydraulic mortar. At some points, it is possible to observe the remains of a vault originally covering the specus. Several 
deformations of different kinds are visible along the walls of the aqueduct, such as cracks, partial collapse of the facing. On some cracks, carbonate concretions have developed during the leakage of water against the wall. Some other deformations are more characteristic of coseismic shaking: some sections of wall show warping, and the upper part of some walls are deformed and "pushed" outward.

Several phases of construction and restoration can be observed. The building visible today was built during the reign of Hadrian (117-138; Sahin, 1979) and restored at the time of Justinian (525-565) according to Procopius (De aedificiis, V, 3). According to Foss (1996), restorations were also done by Theodore I Lascaris (1205-1222) in the 13th century. It is difficult to know precisely when the aqueduct stopped working. Around 1335, the traveler Ibn Battuta (2.452f, cf. Defremery and Sanguinetti (1968)) visited the city a few years after the Ottoman conquest and related that the water supply came from wells. He did not mention any aqueduct, so we could infer that it had already stopped working at that time. However, later witnesses describe an aqueduct in use (Raby, 1976). The clergyman John Covel, who visited Iznik in 1677, wrote that the aqueduct brings a "very good" water, "run[ning] plentifully". Richard Pococke mentioned in the 18th century the existence of an irrigation system going inside the city walls and supplying basins. Nowadays, the population uses other water sources and ways in addition to the ones formerly used by the aqueduct, so it is difficult to know if the irrigation systems mentioned after the Ottoman conquest are exactly similar to the original route of the aqueduct.

We present here the results of a building stratigraphy study of the aqueduct on the $600 \mathrm{~m}$ long section close to the city (Fig. 2), conducted mainly in June and July 2015. An additional geophysical survey was carried out on the underground section in July 2016.

\section{Geographical and geological context}

The city of Iznik stands on the eastern shore of Iznik Lake, the largest freshwater lake of the Marmara region and a depression of tectonic origin, most probably (Dogan et al., 2015; Fig. 1a and c). The southern part of the lake is especially controlled by the middle strand of the North Anatolian fault (MNAF), a major and highly active strike-slip fault system that accommodates the relative motion of the Eurasian and Anatolian tectonic blocks. While most of the horizontal tectonic deformation is localized along the east-west trending segments of the MNAF, a part of the vertical deformation of Iznik Lake basin is accommodated by secondary faults of different orientation, such as the Elbeyli fault, a NW-SE normal fault that borders a carbonate massif east of Iznik. This tectonically active setting is associated to several destructive earthquakes that affected Nicaea. Several major earthquake events struck the city in the last 2000 years and are described in numerous historical chronicles, in 29-32, 121, 362, 368, 740, 1065, 1860, 1875 and 1893 CE (Ambraseys, 2009). While some of these events are generally associated with the northern strand of the NAF, others affected more specifically the Iznik area and may have 
nucleated on the MNAF. Several palaeoseismological trenches opened on the MNAF segments evidenced one rupture south of Iznik in the last 400 years and two ruptures in Gemlik between 1100 and 1800 CE and after 1800 CE respectively (Dogan, 2010; Özalp et al., 2013).

From a geological point of view, Iznik stands on the soft alluvium deposited by the lake during the Quaternary. The city is bordered in the east by a carbonate massif including alternations of marble and schist. South of the MNAF, the Samanli mountains present in the vicinity of Iznik volcano-clastic rocks, limestones, and a detrital sequence (Yilmaz et al., 1995).

\section{Methods}

We focused our study on the northern facing, the southern side being largely inaccessible due to vegetation and private ownership. To study the construction, we used a method developed and implemented especially for several Roman hydraulic buildings in France and Italy (Dessales, 2017; see also Bukowiecki et al. (2008) for an example in Ostia). The studied sections were thoroughly described in terms of construction techniques and materials. These criteria were used for the stratigraphical analysis of the standing remains. They allowed us to identify 43 built stratigraphical units (US). Each of these units was registered with a US number. On these units we also measured characteristic architectural features such as joints and construction stones dimensions. At the scale of the whole building, we used a second registering system to group together the construction techniques encountered which showed strong similarities with each other. These technical groups were also given specific numbers (eg. MR-0028) and registered in a database (ACOR) through synthetic forms including detailed characteristics (morphology, materials, stone dimensions and arrangement...) and photographs. The ACoR base has been developed since 2014 as part of an atlas of the construction techniques in the Roman world (see http://www.transfers.ens.fr/atlas-des-techniques-de-construction-dans-le-monde-romain). This base currently includes techniques from several sites in Italy, Turkey and Morocco. Each technique number is composed of two letters that indicate the type of structure (MR for a wall, AR for an arch, CF for a buttress) and four digits related to its creation rank in the whole database. Finally, the stratigraphical units were grouped into several main building stages showing a technical and/or structural coherence. This allowed us to propose a chronology of the construction.

\section{Description of the techniques of construction observed}

From the detailed survey of the northern facing of the aqueduct, we were able to distinguish fifteen different techniques on ten walls, four arches and one buttress. They mostly use irregular rubble, regular frameworks of quadrangular rubble stones sometimes alternating with courses of terracottas, and regular frameworks of terracottas. In addition of terracottas, the masonries 
use in general limestone, travertine rubble, and spoil materials from other buildings. These materials can be exploited in the environment surrounding the city. Marble and travertine deposits are easily found in the carbonate massif located east of Iznik in the vicinity of Dereköy village, while several limestone outcrops exist in the south and east of the city between Dirazali and Kaynarca (Fig. 1c).

\subsection{Techniques $M R-0028$ and $A R-0004$}

The arches and walls close to the fortifications of Nicaea present a clean, regular framework of alternating bands of 1-3 courses of $4 \mathrm{~cm}$ thick terracotta (probably bricks) and one course of rubble limestone, travertine and marble spoil (MR-0028, Fig. 3a). The terracottas have a bright red matrix and a homogeneous quality (detail photographs are displayed in Supplementary material, Fig. S1 and S2). The terracotta bands are generally composed of only one course but occasionally show two or three layers using smaller or pieces of terracottas. A few dressed terracottas were also found between some rubble stones. The stones are poorly carved and of various sizes, with average dimensions of $20 \times 30 \mathrm{~cm}$.

The same terracottas are used in the arches associated with these walls (AR-0004), with a maximum length of $35 \mathrm{~cm}$.

\subsection{Techniques MR-0034 and AR-0002}

A significant length of the section studied is made of a regular framework of quadrangular travertine stones (MR-0034, Fig. 3b). The ashlars were carefully cut into parallelepipeds, about $40 \mathrm{~cm}$ long. The distribution of their short modulus shows that they can be divided into two batches, arranged vertically most of the time. The upper courses use $12 \mathrm{~cm}$ thick flat rubble while the base of the elevation is made of larger, square or rectangular blocks. This technique is especially characterized by the homogeneity of the materials used which are mainly travertines.

A resembling technique was used for the facings of arches 4 and 7 (Fig. 3c) which use exclusively very well carved travertine rubble blocks of homogeneous dimensions (AR-0002).

\subsection{Techniques CF-0006 and MR-0033}

At the eastern end of the section studied, the direction of the aqueduct changes to the southeast. This change is associated to a reinforcement structure added against the channel on its northern side (Fig. 4a). This structure is entirely made of all similar, finely crafted, $5 \mathrm{~cm}$ thick and $28 \mathrm{~cm}$ long terracottas (bricks), of red-orange colour and containing few visible temper (CF-0006).

The same terracottas are found in another peculiar structure located closer to the city gate and interpreted as a repartition basin. The upper part of this structure is made of a regular framework composed of an alternation of 2-3 terracotta courses with a course of dark marly limestone rubble (MR-0033, Fig. 4b). The stones have homogeneous dimensions, around $10 \times 25 \mathrm{~cm}$. 
The section located between arch 7 and the repartition basin is made of a loosely assembled regular framework composed of an alternation of terracotta courses and limestone rubble (MR0041). The terracotta courses are often hardly visible, especially in the western section, but are obvious in some parts where the collapse of the facing makes the nucleus visible. The rubble stones have average dimensions of $17 \times 31 \mathrm{~cm}$ and are quite poorly carved in general. The few terracottas measured present an average thickness of $4.5 \mathrm{~cm}$.

In the present state of the aqueduct, it is possible to see in places terracotta arches in the nucleus of the building, covered by a stone facing, possibly during a unique construction stage. These inner arches are all very similar to each other and use $5.5 \mathrm{~cm}$ thick and $26 \mathrm{~cm}$ long red-orange terracottas. This type of terracotta is restricted to this technique, assembled with a rather fine, white mortar (AR-0003).

\subsection{Techniques MR-0036, AR-0005 and MR-0143}

A significant length of the section studied uses a regular framework of quadrangular limestone and travertine rubble with a few marble spoils (MR-0036, Fig. 5a). The stones are quite carefully cut, especially the travertines, with average dimensions of $12 \times 31 \mathrm{~cm}$, which makes it close to MR-0034. A peculiarity of this technique is the presence of two very neat flat levels underlined by a course of flat travertine stones. It seems that the limestones were almost exclusively used for the lower courses while the travertines are restricted to the upper courses. This technique is found closely associated with the travertine arch 8 (AR-0005).

Under the bridge of the Iznik-Orhangazi road, the aqueduct presents a loosely assembled, regular framework of limestone and travertine quadrangular rubble, with a significant amount of spoils (Fig. 6, continued in Supplementary material as Fig. S3). The overall technique has some similarity with MR-0036 but uses overall poorly cut stones of various dimensions (MR-0143). The facing of the specus, made of limestone rubble, is likely to be linked to another intervention.

\subsection{Technique MR-0035}

This technique is a regular framework of quadrangular rubble characterized by the exclusive use of rather well-cut limestone rubble. It is found at limited locations along the aqueduct, especially east of the Iznik-Orhangazi road bridge, in the low and middle parts of the facing (US215 and US217, Fig. 6). Similar stones are found in several other techniques and may have been reused from this technique.

\subsection{Technique MR-0142}

This technique is mainly restricted to the specus facing and is made of irregular small limestone rubble including a green rock which is only found here. The rubble stones are not cut as parallelepipeds but present homogeneous dimensions, about $10 \times 15 \mathrm{~cm}$ (Fig. 5b). A similar 
technique is also found in the facing supporting the specus in the easternmost part of the section studied, with occasional use of travertines.

\subsection{Technique MR-0038}

On a limited length, in the middle of the section studied, we found a very peculiar technique using terracottas, and large travertine and limestone rubble (displayed in Supplementary material as Fig. S5). The technique is made of alternations of one rubble course and one terracotta course. It is very distinct from all the other techniques visible on the aqueduct, because each rubble stone of the same course is separated by a dressed terracotta. The rubble stones have quite homogeneous dimensions, about $30 \times 40 \mathrm{~cm}$. The travertine stones are well cut in parallelepipeds contrary to the limestones. The terracottas are $4 \mathrm{~cm}$ thick and present a red matrix. Their quality and dimensions seem rather homogeneous, especially for the dressed terracottas. We also noticed that this technique uses a mortar rich in coarse grains (from $5 \mathrm{~mm}$ to several $\mathrm{cm}$ ). This technique was clearly recognized on the southern facing as well.

\subsection{Technique MR-0144}

This technique corresponds to a modern restoration of the top of the specus present on a significant length of the section studied (Figs. 3a, c, 5a). The restoration uses a very dark cement of granular aspect and mainly poorly cut marble stones of various dimensions.

\section{Chronological bounds}

In US209, $1 \mathrm{~m}$ east of arch 8, we could find a flat Turk gravestone used in the masonry. This indicates that it was built after the first arrival of the Turks in the region during the 11th century. Such a reuse of Turk gravestones in public buildings has been well documented on the defensive walls and is exclusively found in the reconstructions by Alexios I Komnenos shortly after 1097 (Foss and Winfield, 1986). We could then infer a late 11th-early 12th age for this part.

We have also seen that several techniques reuse architectural elements from former buildings, especially the theatre. These spoils were also found in the defensive walls for the reconstructions of the 8th and 9th century during the reigns of Leo III and Michael III.

Another solid technical analogy can be done between the mixed regular framework visible close to the city gate (MR-0028) and several similar techniques found in the defensive walls, classified by Foss and Winfield (1986) as D1, D2 for the former and D4 for the latter. In general, these techniques are dated to the Komnenoi (1097-1185) and Lascarid periods (1208-1258). This is the only real possible analogy with the defensive walls in terms of construction techniques. Apart from these late works, it seems that most of the construction of the aqueduct was undertaken during distinct operations, unrelated to the city walls. 
In order to get absolute time constraints, pieces of mortar and terracottas were also sampled in different units. No charcoal was found in the mortars and the terracottas could not be dated by archaeomagnetism because of their alteration. A sample of carbonate concretion was also dated by ${ }^{14} \mathrm{C}$ but provided a very recent age.

\section{Relative chronology of the building phases}

Using the stratigraphic and typological evidence collected, we propose a construction history in nine phases, summarized on Figs. 7 and 8.

\subsection{Phase 1}

The masonries interpreted as the earliest construction phase visible today are composed of regular alternating courses of terracottas and quadrangular limestone rubble (MR-0041). This phase is visible on limited sections east of arch 7 (US100) as it was obviously extensively replaced by later phases. It is then visible again east of the repartition basin identically (US020, Fig. 5a). The few terracottas visible at the very base of this basin (US212, Fig. 4b) are likely to be a remnant of the same phase. The base courses visible under the bridge and eastward use the same mixed regular framework and are remnants of the same phase (US019, Fig. 6). The terracottas used in these units show very specific dimensions, about $5 \times 30 \mathrm{~cm}$. The fact that these same dimensions are found for the inner arches (US002, US006 and US007, AR-0003, Fig. 5b) suggests that we can relate these arches to the same early phase. US020 and US100 show that this technique was used on the whole height of the aqueduct, probably including the specus. As the earliest phase found, we could associate it with Hadrian's original construction or the rebuilding of Justinian mentioned by Procopius.

\subsection{Phase 2}

This phase is preferentially found in the western part of the section studied and includes lower and intermediate courses using a regular framework of quadrangular limestone rubble (MR0035). It was seen east of the Iznik-Orhangazi road bridge, apparently replacing phase 1 (US215, Fig. 6b) and also as a new facing for arch 12 (US014, Fig. 5b). It is difficult to determine whether this phase represents occasional local repairs of the facing or if it was a more extensive rebuilding which was then replaced by later phases.

\subsection{Phase 3}

We have chosen to group in the following phase two different kinds of work. The first one (phase 3a, fig. 7) is characterized by a specific, good quality, type of terracottas and corresponds to particular functional elements: a buttress at the eastern end of the section studied (US018, CF0006, Fig. 4a) and a probable repartition basin closer to the city gate (US021, MR-0033, Fig. 4b). The wall supporting the specus visible today, which bypasses the buttress on the south, may be 
the result of later interventions and reconstructions. The second work (phase $3 \mathrm{~b}$ ) regroups several extensive reconstructions carried out especially on the specus east of the bridge (US012, US017, US210, US213, Figs. 5b and 6) and on some parts of the supporting courses. It is characterized for the specus by a specific technique MR-0142 using smaller stones. Stratigraphically, it lies directly on the terracottas of phase 3a. This is clearly visible at the junction between the buttress and the specus, where there is no apparent discontinuity between the similar mortars of both frameworks. It can thus be deduced that they were probably built during one or two successive projects at the same period of time. It is remarkable that phase $3 \mathrm{~b}$ is today totally absent in the western part of the aqueduct (Fig. 7), as it was replaced by later works.

\subsection{Phase 4}

On several portions of the aqueduct, the limestone framework of the specus from phase $3 b$ is heavily damaged and sometimes entirely replaced by travertines. Among the travertine works, the earliest phase is very limited in length, especially visible in the centre of the section studied (US015) and characterized by the use of technique MR-0038. It seems that these masonries reuse the limestone rubble of phase 2 and the stratigraphy of the construction indicates that it predates the other phases using rectangular blocks of travertine.

\subsection{Phase 5}

This phase represents a significant part of the masonries visible on the aqueduct today and is characterized by an almost exclusive use of travertine stones (MR-0034). This phase is visible close to the city gates on the southern facing of arch 7 (Fig. 3c). This part of wall displays a succession of several interventions. The top of the current low arch is made of travertine stones (US203) masking a terracotta arch present in the nucleus similarly to AR-0003 (phase 1). This inner arch makes then way for a lower arch with a facing composed of smaller travertine rectangular stones (US003). By analogy, we can include in this phase the northern facing of the low arch 4 (AR-0002).

The same phase is also visible around arch 9 (US005, Fig. 3b) and seems to alternate with other interventions, maybe contemporary or closely related, which use more limestones (US010). We may also include in this phase the intermediate courses of the facing of the sections located east of the Iznik-Orhangazi road bridge (US013, US214, Fig. 6b). The technique is characterized by an almost exclusive use of well-cut travertine stones, with a flat rectangular shape most of the time. Less frequently, bigger squared travertines similar to MR-0038 were used (US023). The works of phase 4 also include a new travertine facing for the specus.

\subsection{Phase 6}

We have chosen to group in this phase several reconstruction works that use regular frameworks of quadrangular rubble. They are characterized by a great diversity of materials: travertines, 
limestones and spoils from other building. This phase is found on the section passing under the Iznik-Orhangazi road bridge, and probably follows a large collapse of the upper facing (Fig. 6a). The reconstruction seems to have been quick and not really programmed: the masonry is of bad quality, the material used are of various types and include many big marble spoils (US216, MR0143) probably taken from the theatre. By analogy with the large use of similar spoils in the defensive walls, we could date this reconstruction 6 a to the 8-9th centuries, but it could also be a much later intervention.

To this phase we also associate arch 8 (US004, AR-0005) and the surrounding wall (US209, Fig. 5a) until the bridge (US011) with some discontinuities (MR-0036). The bases of the repartition basin (US022, Fig. 4b) and the buttress (US211, Fig. 4a) were also included in this phase. The presence of several spoils in the masonry, especially a Turk gravestone, may indicate that this phase is a reconstruction that follows the seizure of the city by Alexios I Komnenos in 1097 . The mixture of materials used can be understood as a way to rebuild in emergency with few new materials available. It is interesting to note that while this phase includes the new northern facing of arches 4, 7 and 8, only the latter shows a very different, uncommon shape, and stone voussoirs of different sizes. These observations suggest that arch 8 was significantly more damaged and needed to be rebuilt entirely. On this section, we could also note that while the main portion of the wall uses limestones, the facing of the specus is also made of travertines (US208, MR-0034), which may have been preserved or reused in imitation from phase 4.

Given the significant technical variations observed in the different reconstructions attributed to this phase, it is likely that they were not all build in a unique chantier. For some sections, the travertines of phase 4 are predominant but associated with new materials. For others, these new materials are predominant and the joints are better conserved, indicating a different and probably later intervention (phase 6b). However, it was generally difficult to find a clear stratigraphical rupture between all these rebuildings. We chose to group them into one unique phase representing several successive works around the 11th century.

\subsection{Phase 7}

Phase 7 is limited to the section closer to the city walls, between arches 2 and 8 (Fig. 3a and c). While the arches are made of terracottas (US001, AR-0004), the surrounding wall uses a mixed regular framework with the same type of terracottas (US008 and US205, MR-0028), alternating with quadrangular rubble courses. This phase is characterized by a good quality construction. It was even used as a model for the very recent restoration works which sometimes overprint different techniques. The vicinity of this phase to the city walls could indicate that it is a late Byzantine intervention linked to the construction of the outer wall by John Vatatzes (1222-1254) in the 13th century. Analogous techniques found in the walls also suggest a late date between the 12 th and 13 th centuries. 
This phase represents a modern cement restoration (MR-0144) on parts of the specus (US016, US024, US201, US204, US206; Fig. 5a) and is probably one of the last interventions realized on the aqueduct. Some arches, namely arch 7 and arch 8, were also filled with stones at unknown periods. However, these two late interventions are distinct: while arch 7 was filled with irregular rubble using similar materials to phase 5 (US202), the filling of arch 8 is made of large limestones without mortar (US207).

\subsection{Phase 9}

From 2015 onwards, new restorations were made on the sections of the aqueduct close to the city gates. They imitate the technique MR-0028 of phase 8 (US200, Fig. 3a).

\section{On-fault displacement of the aqueduct east of Iznik}

The western border of the carbonate massif east of Iznik is delimited by a normal fault, the Elbeyli fault, which clearly separates it from the flat alluvial plain of the lake. The trace of this fault is expected at its southern termination to cross the aqueduct.

All along its visible remains, a precise topographic survey of the channel of the aqueduct was done with GPS RTK, with a vertical $2 \sigma$ uncertainty of $5 \mathrm{~cm}$ (Fig. 9). In addition, shallow geophysical imaging was performed using Ground Penetrating Radar (GPR) along several transverse profiles in order to locate the buried path of the aqueduct (Fig. 10). For this, a ProEx system provided by Mala Geoscience was connected to a $250 \mathrm{MHz}$ shielded antenna, which provides a wavelength of around $25 \mathrm{~cm}$ in the limestone formation (assuming a velocity of $10 \mathrm{~cm} / \mathrm{ns}$ ). Each GPR trace was acquired every $10 \mathrm{~cm}$ using a sampling frequency of $2.5 \mathrm{GHz}$. In this context, the GPR signature of the top of the buried aqueduct could be the presence of diffraction hyperbolas. Fig. $9 \mathrm{~b}$ shows the result of the topographic survey superimposed on the local topography obtained from the Pleiades DEM. Most of the measurement points were taken on the bottom of the channel. Along the underground section, it was generally not possible to reach the base of the channel because it was filled with collapsed material and soil, so the points were measured closer to the vault of the channel. Relying on the aqueduct sections close to Iznik gates, where the vaulted channel is preserved, we can estimate the height of the channel to about $1 \mathrm{~m}$. On the sides of the massif, both sections of the aqueduct show a gentle slope progressively decreasing from $\sim 0.4$ to $0.15 \%$ westward. A higher slope is visible on the western border of the massif, where the aqueduct seems to follow the topography. At this point, a basin was built to drop the water pressure caused by this locally higher gradient. The central section of the aqueduct looks upthrown relatively to the sides. This vertical offset is higher near the fault compared to the centre of the underground section. 
From the two-way travel times of the GPR reflections, 2D plots of horizontal distance versus travel time were constructed with the Seismic Unix software (Stockwell Jr., 1999). Fig. 10 presents the GPR profiles where the underground channel is the most visible (the other profiles are displayed in Supplementary materials). This is especially the case in the southeast where a shallow terracotta construction is accessible by two successive holes in the ground (profiles 1 to 6 on Fig. 10, field photographs are displayed in Supplementary material as Fig. S6). In the central part along the slope of the massif, the structure is much more difficult to see (i.e. profiles 10 and 15) and is invisible on some profiles. This could imply that it has been destroyed or that the channel is filled with the surrounding soil and cannot be distinguished by GPR. It is interesting to note that the structure is more visible at the tips of the underground section, where the carbonate substratum is closer to the surface and sometimes outcropping. This may explain why the GPR better images the structure in these areas, which offer a higher resistivity and a lowest attenuation. At the northern tip of the underground section, the channel is evidently dug into the carbonate rock. The GPR data do not enable us to detect significant depth variations for the channel in the central section.

The two profiles 15 and 14 are respectively located on the footwall and hanging wall of the fault. On profile 14, it is possible to see a bell-shaped anomaly below $60 \mathrm{~ns}$ which can be interpreted as the channel. It appears here deeper than on the other profiles on the south where similar anomalies appear at 15-20 ns. As the local topography decreases westward, the channel here should instead appear at a smaller depth. Given that the nature of the surrounding material is not significantly different between the profiles, probably with an intermediate resistivity between limestone and clay, this implies that the channel is downthrown west of profile 15 . We can qualitatively estimate the depth difference associated. Taking a velocity of $10 \mathrm{~cm} / \mathrm{ns}$ for carbonates, this $40 \mathrm{~ns}$ difference corresponds to $2 \mathrm{~m}$.

Our field measurements evidenced two vertical offsets on the aqueduct at its intersections with the supposed fault trace. The eastern offset is around $50 \mathrm{~cm}$. The western offset is more difficult to measure because the aqueduct obviously follows partly the topography, so a portion of the vertical difference observed may be original. The mapped trace of the Elbeyli fault has a total length of about $7 \mathrm{~km}$. An earthquake rupturing the whole fault length is expected to produce no more than $\sim 20 \mathrm{~cm}$ of displacement, with a maximum magnitude of Mw 6 (Wells and Coppersmith, 1994). The Elbeyli fault has never been documented as a significantly active structure and there is actually few clear evidence of recent faulting along-track. The archaeological markers presented here might indicate that this fault has the ability to slip conjointly with the MNAF during big ruptures or independently during smaller earthquakes. The latter mechanism is much less probable given that the main compressive stress in the area is perpendicular to the orientation of the Elbeyli fault. The observed displacements interrupted the use of the aqueduct and we did not find evidence of repair on the field. This suggests that the deformations happened later than the last works of the Lascarids documented near the city gates. Possible candidates for this deformation phase are rather scarce in the seismicity catalog. 
The time range matches the rupture found in a trench south of Iznik (Dogan, 2010; see Section 2). The events of the 19th century are described as small ruptures and are not likely candidates (Ambraseys, 2009). Another possibility is a bigger rupture after the Ottoman conquest, like the 1419 earthquake that damaged Bursa. Although no such earthquake is known explicitly for Iznik, the first rupture identified in the trench of Özalp et al. (2013) in Gemlik makes this scenario credible. More archaeological field work and excavations are needed to precise the timing of these deformations and to check whether the aqueduct was consequently abandoned or rebuilt, as was observed on other similar sites (Galli and Naso, 2009; Passchier et al., 2013).

\section{Conclusions}

Our building stratigraphy and typology of the construction techniques approach enabled us to propose a construction history for Iznik aqueduct, extending from the Roman period to modern times. The oldest remaining masonries may date back from Hadrian or Justinian's reign. In a later project, two specific structures, interpreted as a buttress and a repartition basin, were added and the specus was extensively rebuilt. A second period of construction is marked by a major shift in the materials used, abandoning limestones for well-cut travertines (phase 4). Around the 11th century, much of the facing of the aqueduct was rebuilt, probably after important damages. These multiple interventions reuse a significant amount of the former materials, theatre spoils and Turk gravestones. Interestingly, these reconstructions postpone a major earthquake in 1065 and the fights of the First Crusade in 1097. The last historical works date back from the Lascarid period. They used a new regular framework with alternating courses of terracottas and quadrangular rubble close to the city gates. Modern restorations affected almost the whole length of the specus, and the portion close to the city was very recently restored in a Lascarid imitation style. The early stages of construction could be better dated by comparing the fabric of phases 1 and 3 terracottas with those of Hagia Sophia church in Iznik, which was built during Justinian's reign. The vertical deformation of the eastern section of the aqueduct correlates with the trace of an active normal fault bounding the carbonate massif east of Iznik. The center of the underground part of the building was uplifted by at least $50 \mathrm{~cm}$ during one or several historical earthquakes. The recent activity of this fault segment outside of the principal deformation zone along the MNAF had not been suspected before. Its precise timing should be further investigated with trenching works. These results demonstrate the relevance of the pluridisciplinary approach to document the history of ancient buildings as well as the behavior of major active fault segments and the risk associated. 


\section{Acknowledgements}

This research was funded by the MISTRALS-ENVIMED program (NAFIGEA project), the INSU ALEAS program (France) and LabEx OSUG@2020 (Investissements d'avenir - ANR10 LABX56, France). We thank the Turkish Ministry of Culture and Tourism for allowing the field work. We are also grateful to Mustafa Aktar, Pınar Büyükakpınar, Deniz Ertuncay, Figen Eskiköy from Boğaziçi University Department of Geophysics, and the students from Bursa University Department of Archaeology for their help during the field data acquisitions. We also thank Agnès Tricoche (LabEx TransferS) for her collaboration on the AcoR database, and Yann Klinger (IPGP) for fruitful remarks on the deformation of the aqueduct. We also thank three anonymous reviewers for their valuable comments on the initial manuscript.

\section{References}

Ambraseys, N.N., 2009. Earthquakes in the Mediterranean and Middle East, A Multidisciplinary Study of Seismicity up to 1900. pp. 968.

Bukowiecki, E., Dessales, H., Dubouloz, J., 2008. Ostie, l'eau dans la ville: châteaux d'eau et réseau d'adduction. Ecole Française de Rome, Rome.

Defremery, C., Sanguinetti, B.R., 1968. Voyages d'Ibn Battuta IV. Anthropos, Paris (463 p).

Dessales, H., 2017. L'archéologie de la construction. Une nouvelle approche de l'architecture romaine. Histoire, Sciences Sociales (1), 75-94. https://doi.org/10.1017/S039526491700004X. (72e année).

Dogan, B., 2010. Kuzey Anadolu Fay Sistemi Güney Kolunun Geyve-Gemlik Arasindaki Kesiminin Morfotektonik, Tektonostratigrafik ve Paleosismolojik Evrimi. PhD Thesis. Istanbul Teknik Üniversitesi.

Dogan, B., Tüysüz, O., Sanli, F.B., 2015. Tectonostratigraphic evolution of the basins on the southern branch of the North Anatolian Fault System in the SE Marmara Region, Turkey. Int. J. Earth Sci. 104 (2), 389-418.

Emre, Ö., Duman, T.Y., Özalp, S., 2011. 1:250.000 Ölçekli Türkiye Diri Fay Haritası Serisi, Bursa (NK 35-12) Paftası. Seri No: 9. Maden Tetkik ve Arama Genel Müdürlüğü.

Foss, C., 1982. The defences of Asia Minor against the Turks. In: Greek Orthodox Theological Review. 27. pp. 145-205.

Foss, C., 1996. Nicaea: A Byzantine Capital and Its Praises. Hellenic College Press, Brookline, Mass (224 p).

Foss, C., Winfield, D., 1986. Byzantine Fortifications: An Introduction. University of South Africa Press, Pretoria (298 p).

Galli, P.A.C., Naso, J.A., 2009. Unmasking the 1349 earthquake source (southern Italy): paleoseismological and archaeoseismological indications from the Aquae luliae fault. J. Struct. Geol. 31 (2), 128-149. https://doi.org/10.1016/i.jsg.2008.09.007.

Hasancebi, N., Ulusay, R., 2006. Evaluation of site amplification and site period using different 
methods for an earthquake-prone settlement in Western Turkey. Eng. Geol. 87, 85-104.

Özalp, S., Emre, Ö., Dogan, A., 2013. The segment structure of southern branch of the North Anatolian Fault and Paleoseismological behaviour of the Gemlik Fault, NW Anatolia. Bull. MTA 147, 1-17.

Passchier, C.W., Wiplinger, G., Güngör, T., Kessener, P., Sürmelihindi, G., 2013. Normal fault displacement dislocating a Roman aqueduct of Ephesos, western Turkey. TerraNova 25, 292297. https://doi.org/10.1111/ter.12035.

Passchier, C., Sürmelihindi, G., Spötl, C., Mertz-Kraus, R., Scholz, D., 2016. Carbonate deposits from the ancient aqueduct of Béziers, France-a high-resolution palaeoenvironmental archive for the Roman Empire. Palaeogeogr. Palaeoclimatol. Palaeoecol. 461, 328-340. https://doi.org/10.1016/i.palaeo.2016.08.022.

Raby, J., 1976. A seventeenth century description of Iznik-Nicaea. Istanbuler Mitteilungen 26, 149-188.

Sahin, S., 1979. Katalog der antiken Inschrifften des Museums von Iznik (Nikaia), I. Bonn. (336 p). Sbeinati, M.R., Meghraoui, M., Suleyman, G., Gomez, F., Grootes, P., Nadeau, M.-J., Al Najjar, H., Al-Ghazzi, R., 2010. Timing of earthquake ruptures at the Al Harif Roman aqueduct (Dead Sea fault, Syria) from archaeoseismology and paleoseismology. Geol. Soc. Am. Spec. Pap. 471, 243267. https://doi.org/10.1130/2010.2471(20.

Schneider, A.M., Karnapp, W., 1938. Die Stadtmauer von Iznik (Nicaea). Deutsches Archaologisches Institut.

Seyitoglu, G., Ecevitoglu, B., Kaypak, B., Esat, K., Caglayan, A., Gündogdu, O., Güney, Y., Isik, V., Pekkan, E., Tün, M., Avdan, U., 2015. A missing-link in the tectonic configuration of the Almacik Block along the North Anatolian Fault Zone (NW Turkey): active faulting in the Bolu plain based on seismic reflection studies. Geophys. J. Int. 201 (3), 1814-1833.

Stockwell Jr., J.W., 1999. The CWP/SU: Seismic Unix Package, Computers and Geo-Sciences. (May 1999).

Volant, P., Levret, A., Carbon, D., Scotti, O., Combescure, D., Verdel, T., Piant, A., Laurent, P., 2009. An archaeo-seismological study of the Nîmes Roman aqueduct, France: indirect evidence for an $M>6$ seismic event? Nat. Hazards 49 (1), 53-77. https://doi.org/10.1007/s11069-0089276-9.

Wells, D.L., Coppersmith, K.J., 1994. New empirical relationships among magnitude, rupture length, rupture width, rupture area, and surface displacement. Bull. Seismol. Soc. Am. 84 (4), 974-1002.

Yilmaz, Y., Genc, S., Yigitbas, E., Bozcu, M., Yılmaz, K., 1995. Geological evolution of the Late Mesozoic continental margin of northwest Anatolia. Tectonophysics 243,155-171 


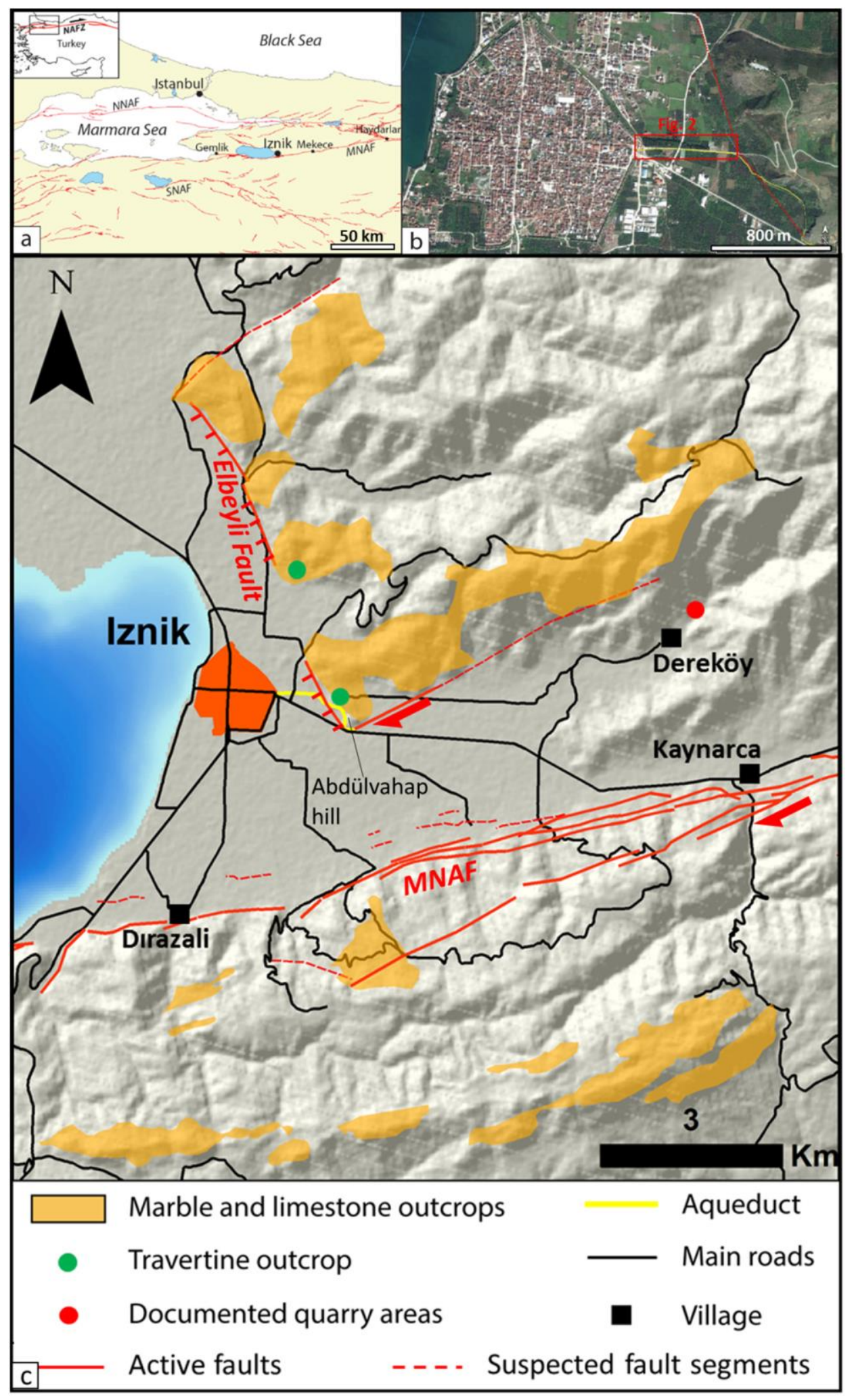

Fig. 1. (a) General location map, with active faults drawn in red (Dogan et al., 2015; Emre et al., 2011; Hasancebi and Ulusay, 2006; Seyitoglu et al., 2015). MNAF = Middle strand of the North Anatolian fault. (b) Satellite view of Iznik on the left, with the visible remains of the aqueduct in yellow. The Elbeyli normal fault is drawn in red. (c) Map of the possible extraction zones for the materials used in the aqueduct. The ancient quarries were visited during the field missions. 

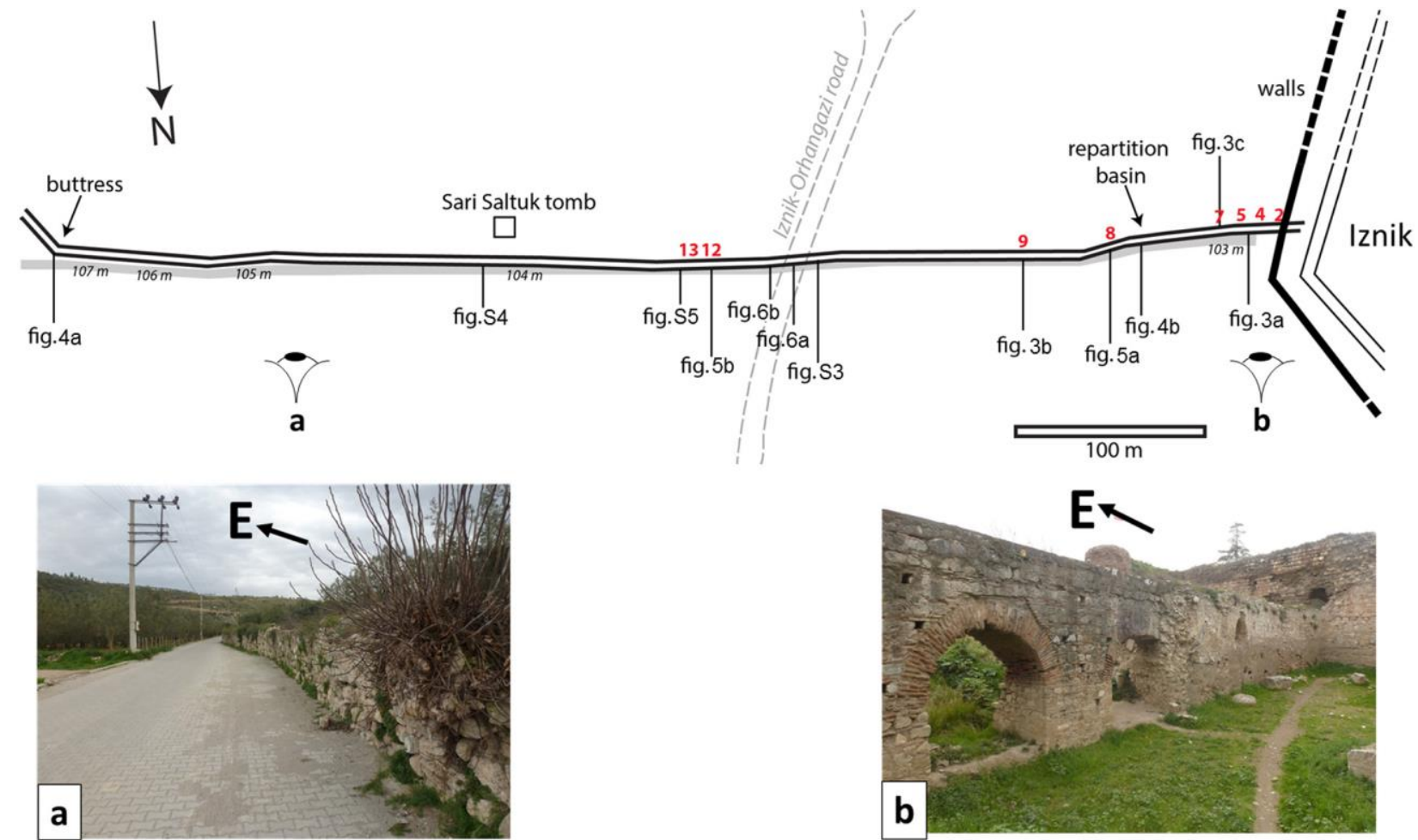

Fig. 2. Simplified sketch of the studied section of the aqueduct with the location of the main observations mentioned in the text. In grey are drawn the roads from Iznik to Abdülvahap hill following the aqueduct and from Iznik to Orhangazi (broken lines). The arches mentioned in the text are located with red numbers. The ground topography along the aqueduct is precised with a few elevations asl. At the bottom, two photos show the apparent height decrease of the building eastward. 

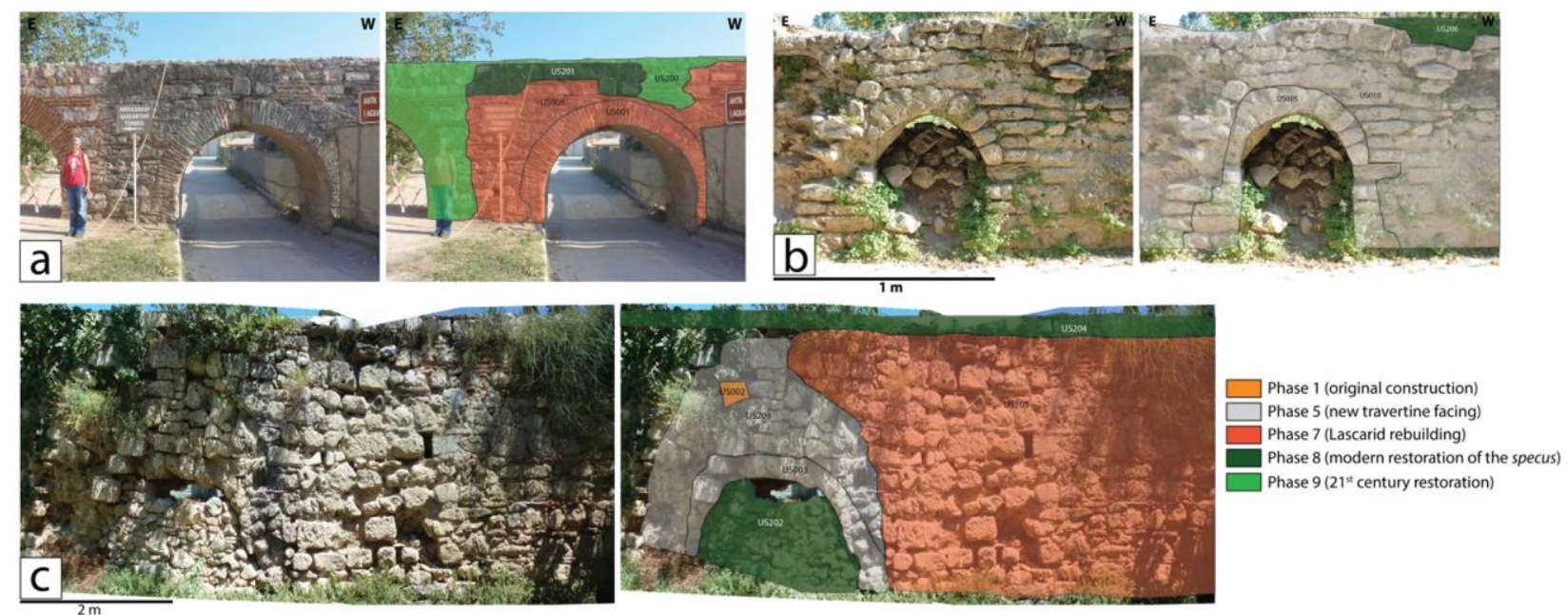

Fig. 3. (a) Stratigraphy of arch 5 and surrounding facings, showing phase 7 (US001 and US008, AR-0004 and MR-0028) and modern restorations (US201 and US200). (b) Stratigraphy of arch 9 and surrounding wall. The whole travertine masonry belongs to phase 5 (MR-0034 and AR-0002). A small modern restoration is visible on the specus (US206, MR0144). (c) Stratigraphy of southern facing of arch 7 and surrounding wall. A terracotta arch from phase 1 is visible in the nucleus (US002, AR-0003) and was later covered by a new travertine facing (US003, US203, AR-0002 and MR-0034) in phase 5. The adjacent wall was much rebuilt in phase 7 (US205, MR-0028) and the specus visible today is the result of modern restoration (US204). 

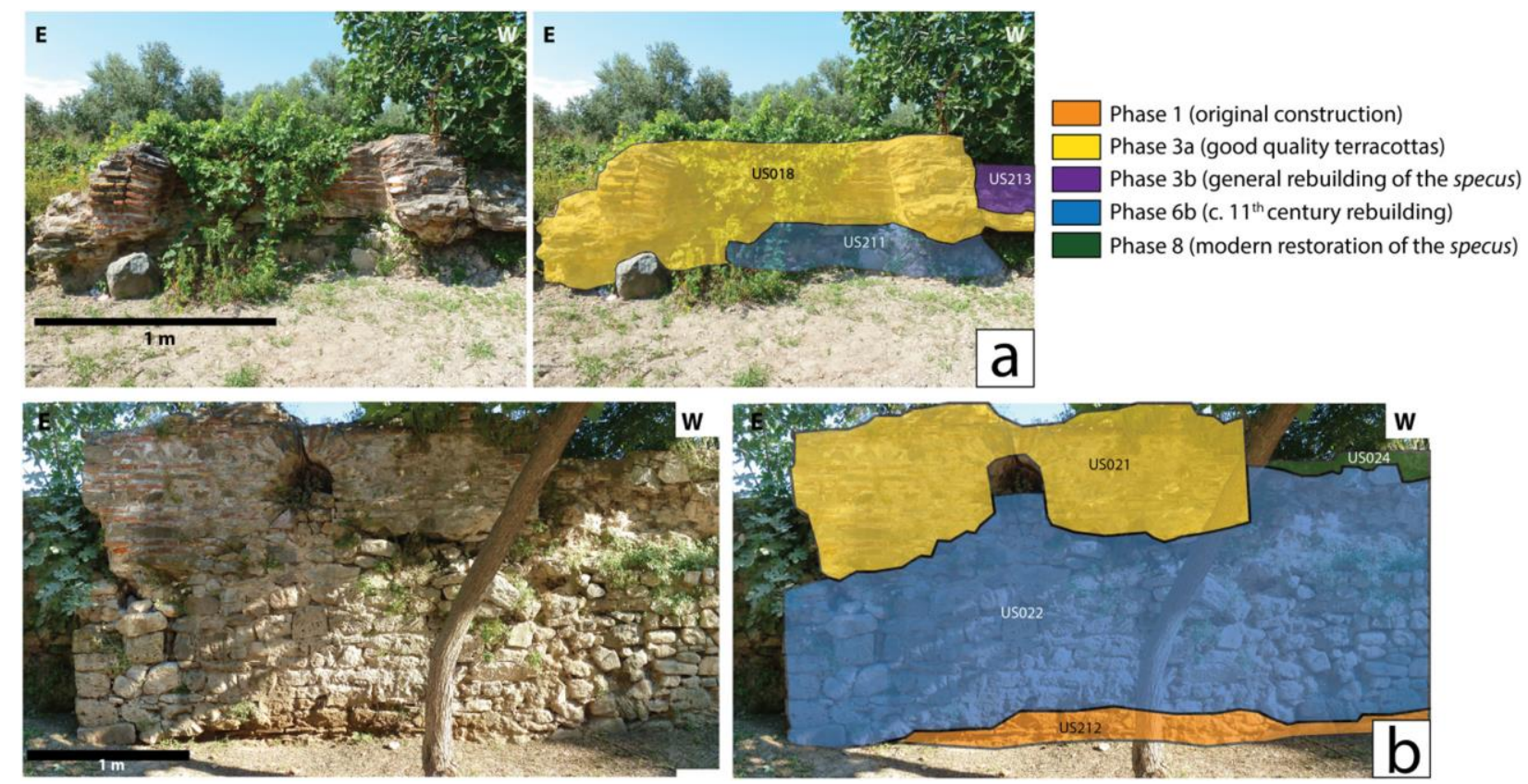

Fig. 4. (a) Stratigraphy of the buttress located at the eastern end of the section studied. The buttress (US018, CF-006) was built in phase 3a and predates part of the base's facing (US211, MR-0036) belonging to phase 6 . On the right, the specus rebuilt in phase $3 b$ (US213, MR-0142) lies on the terracottas of phase $3 a$. Note that here the aqueduct is significantly lower than on the western portions (see for example Fig. 3a for comparison). (b): Stratigraphy of the repartition basin. A remnant of phase 1 masonry is visible at the base (US212, MR-0041). Most of the superstructure's facing is interpreted as a work of phase 6b (US022, MR-0036), while the top courses forming the basin belong to the preceding phase 3a (US021, MR-0033). The adjacent specus was restored during modern times (US204). 

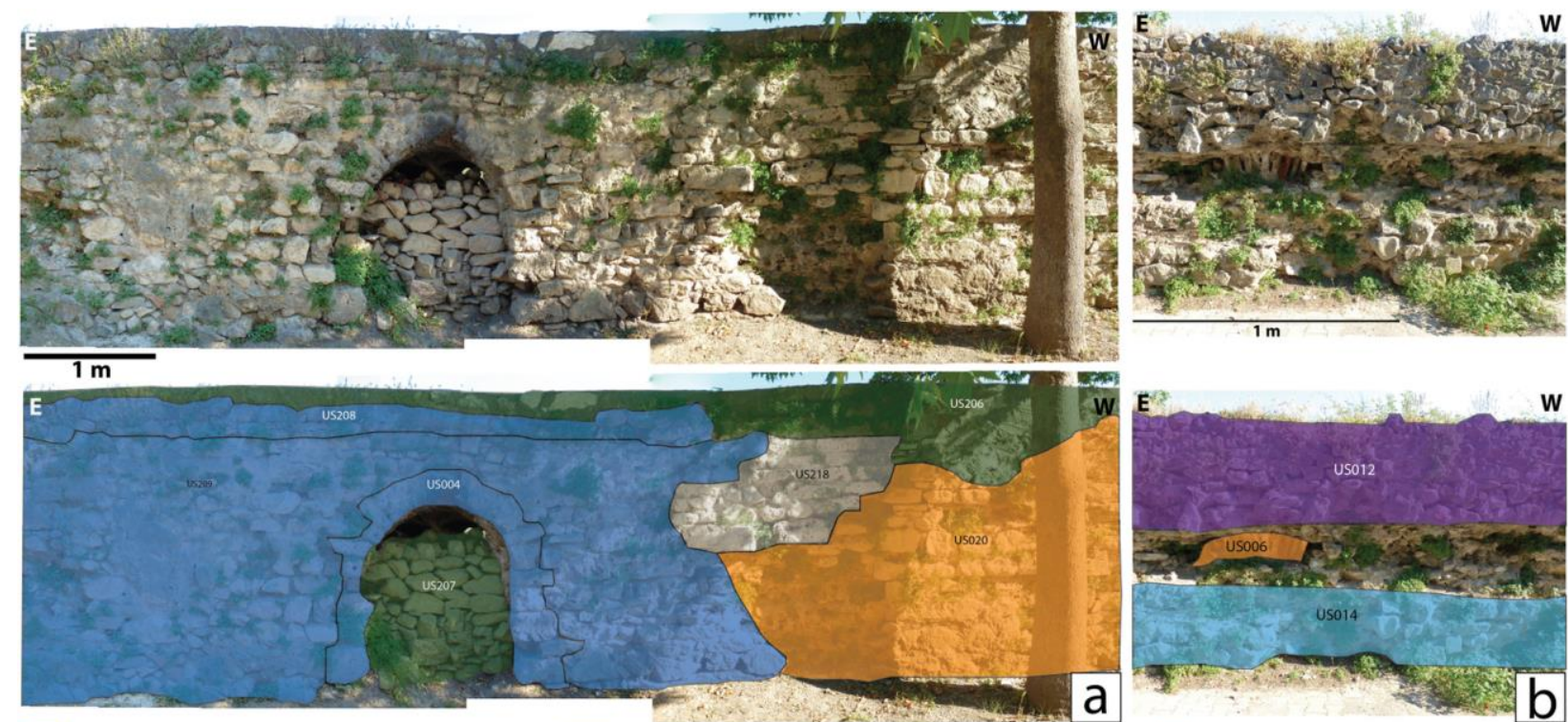

Phase 1 (original construction)

Phase $3 \mathrm{~b}$ (general rebuilding of the specus) Phase 5 (new travertine facing)

Fig. 5. (a) Stratigraphy of arch 8 and surrounding walls. Early phases 1 and 5 are visible on the right (US020, US218 respectively). They were replaced on the left by the reconstructions of phase 6b (US004, US209 and US208). The specus have here been restored during modern times (US206). The filling of the arch (US207) is difficult to date precisely but is probably very late. (b) Stratigraphy of arch 12 and surrounding wall, showing phases 1 (US006, AR-003) and 2 (US0014, MR-0035). The specus (US012, MR-0142) was rebuilt in phase 3b. 

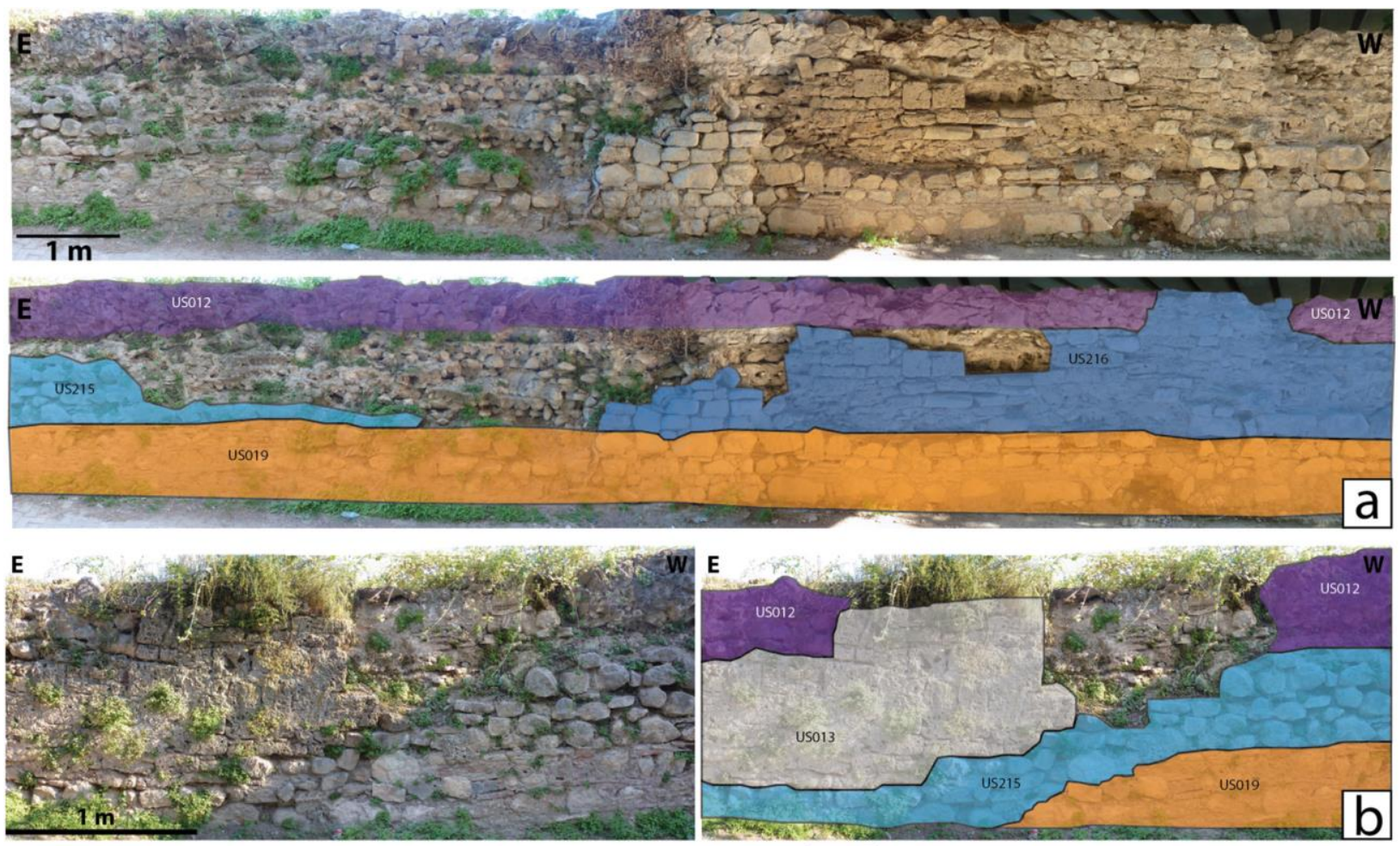

Phase 1 (original construction)

Phase 2 (new limestone rubble facing)

Phase 5 (new travertine facing)

Phase $6 a$ (c. $11^{\text {th }}$ century rebuilding)

Phase $3 \mathrm{~b}$ (general rebuilding of the specus)

Fig. 6. (a) Stratigraphy of the section located west of the Iznik-Orhangazi road. The base courses (US019, MR-041) belong to phase 1. Phase 2 is visible on the left (US215, MR-0035). The specus was almost entirely rebuilt in phase $3 \mathrm{~b}$ (US012, MR-0142). Most of the intermediate courses of the wall are collapsed or covered by a new facing on the right (US216, MR-0143, phase 6a). (b) Stratigraphy of the section east of the Iznik-Orhangazi road bridge. Phases 1 and 2 are present in the right-hand corner (US019 and US215 respectively). The specus visible on the sides (US012, MR-0142) is a reconstruction from phase 3b. A great part of the facing above (US013, MR0034) was rebuilt in phase 5 . 


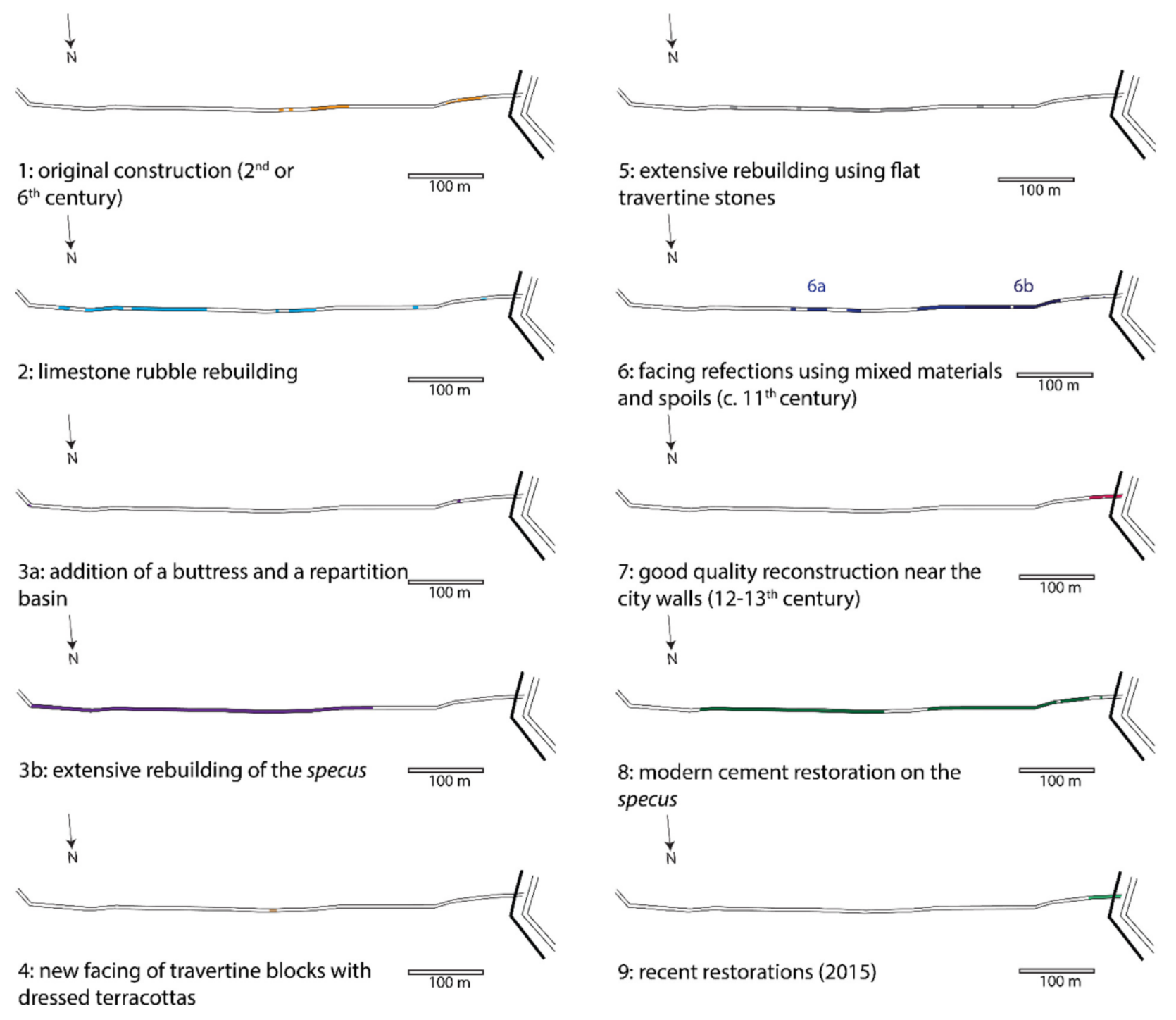

Fig. 7. Location of the different construction phases visible on the aqueduct. 


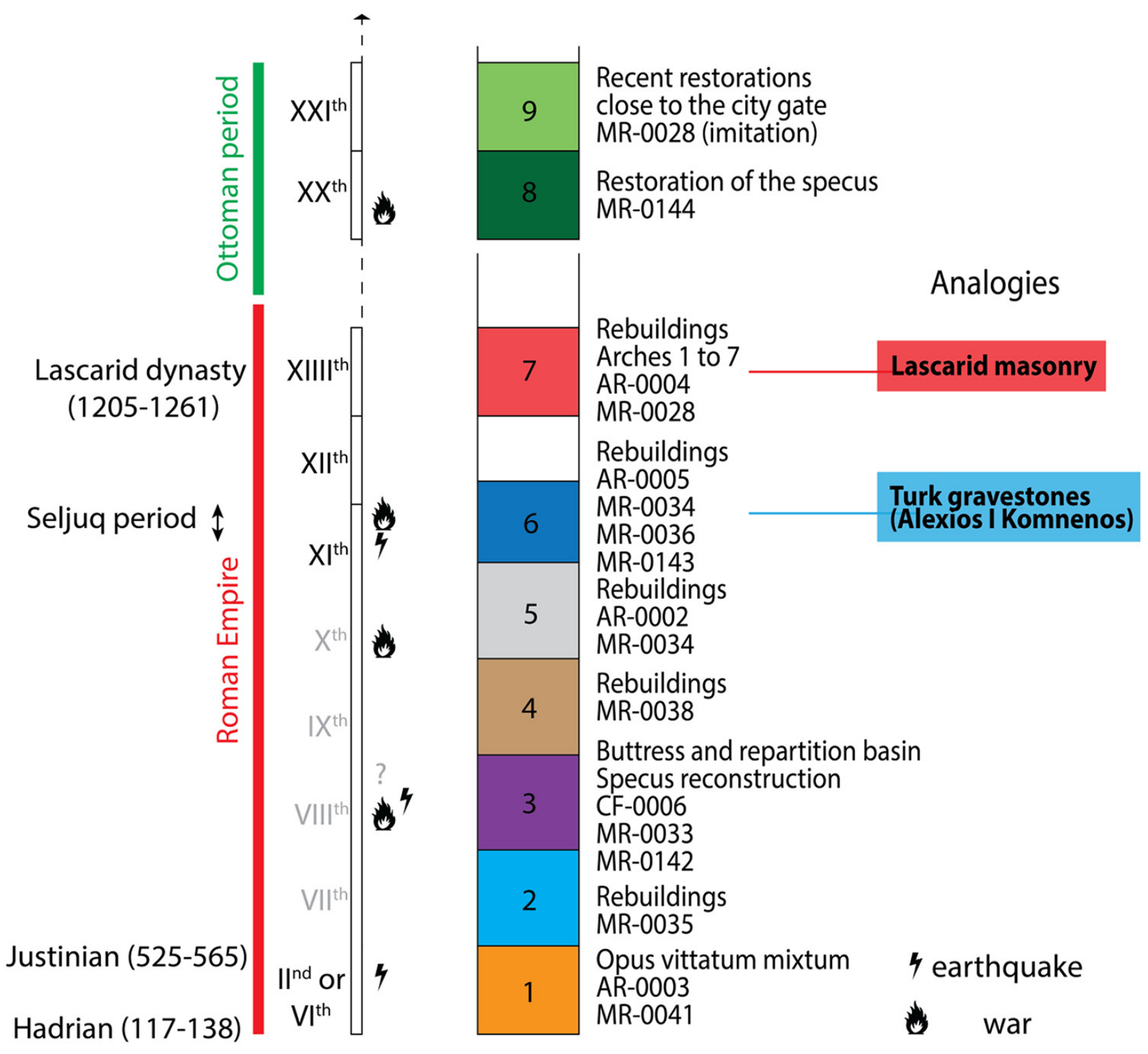

Fig. 8. Hypothetical relative chronology of the construction for Iznik aqueduct, replaced in a timeline thanks to several arguments. On the right are precised possible technical analogies with the walls. Note that the absolute chronology is more uncertain for phases 2 to 5 because precise dating and analogy are missing. 

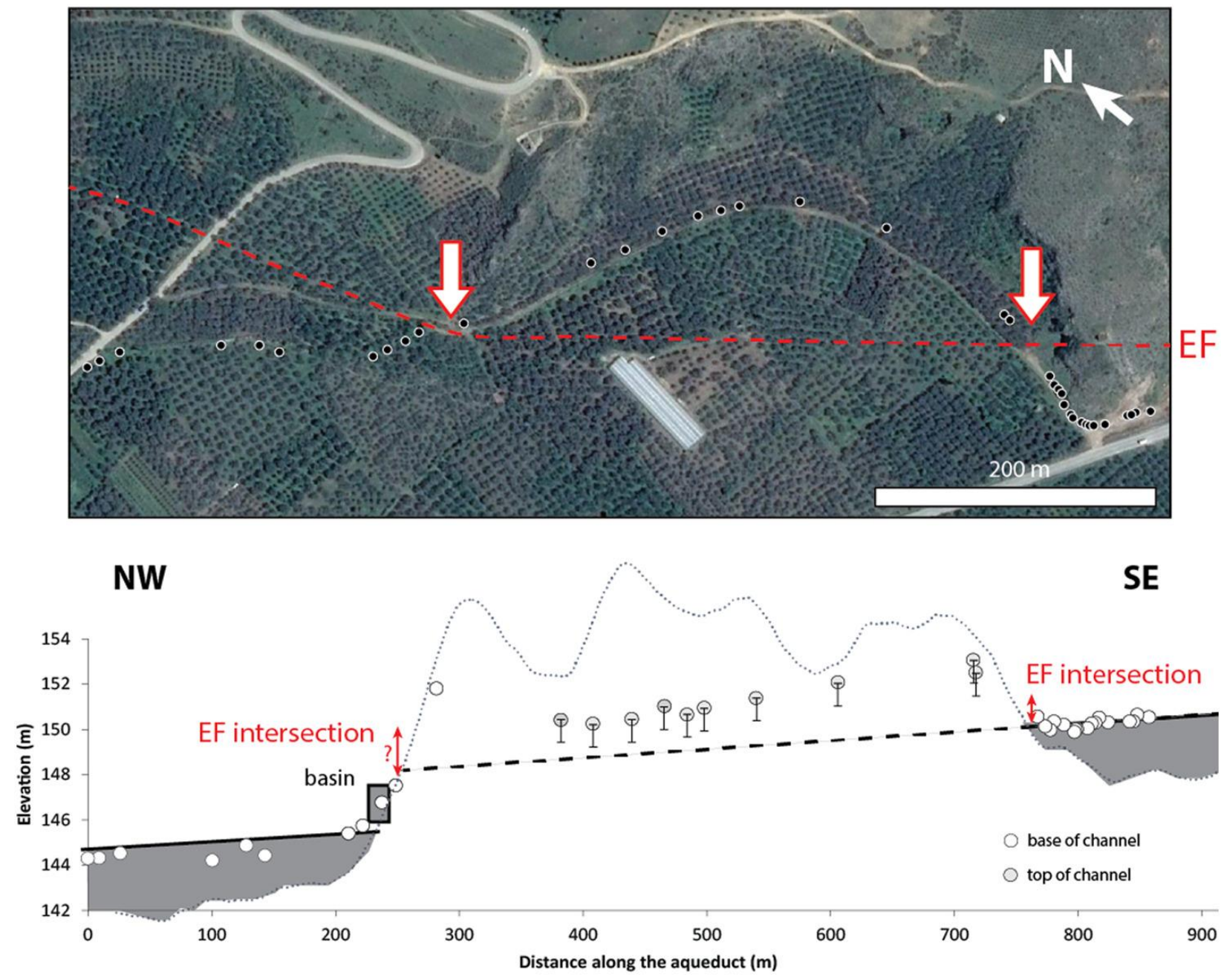

Fig. 9. Topographic survey along the aqueduct on Abdülvahap hill (see Fig. 1c for the location). On the top are localized the GPS measurement points on a Google Earth image. The Elbeyli fault (EF) trace is drawn as a red broken line and its intersections with the aqueduct are indicated with arrows. On the bottom is shown the measured elevations of the channel superimposed on the Pleiades surface topography (black dotted line). The relative vertical uncertainty of the Pleiades DEM is around $50 \mathrm{~cm}$. The Pleiades DEM includes the vegetation cover, which explains its sinusoidal shape. The actual ground level is closer to the minima of the profile. The white dots correspond to the base of the channel while the grey dots were measured closer to its top. The height of the channel (about $1 \mathrm{~m}$ ) is indicated with black vertical bars. The base of the aqueduct, built as a wall running on air on the sides of the hill, is reconstructed in grey. The black broken line represents the original underground channel before its relative uplift. Vertical offsets are visible at both ends of the underground channel. 


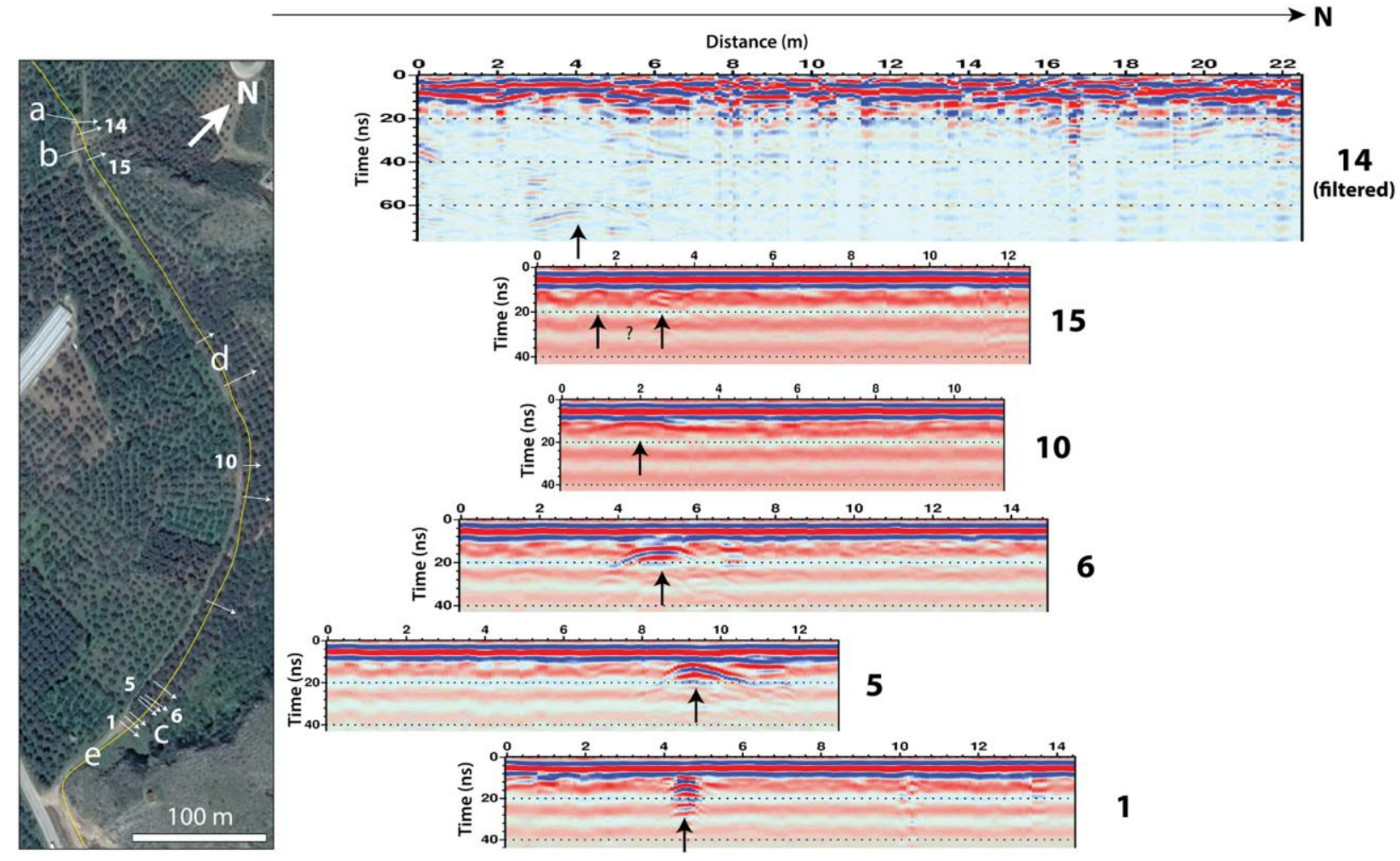

Fig. 10. GPR survey on the underground aqueduct. The map on the left locates the channel in yellow and the transversal GPR acquisitions drawn as white arrows. The numbers correspond to different GPR profiles. The letters locate the field photographs displayed in Supplementary materials in Fig. S6. On the right are shown the GPR images on which the aqueduct is most visible (black arrows). To improve the visibility of deeper arrivals on profile 14, a different gain was applied and the plane wave arrivals were suppressed. 


\section{Supplementary Material}

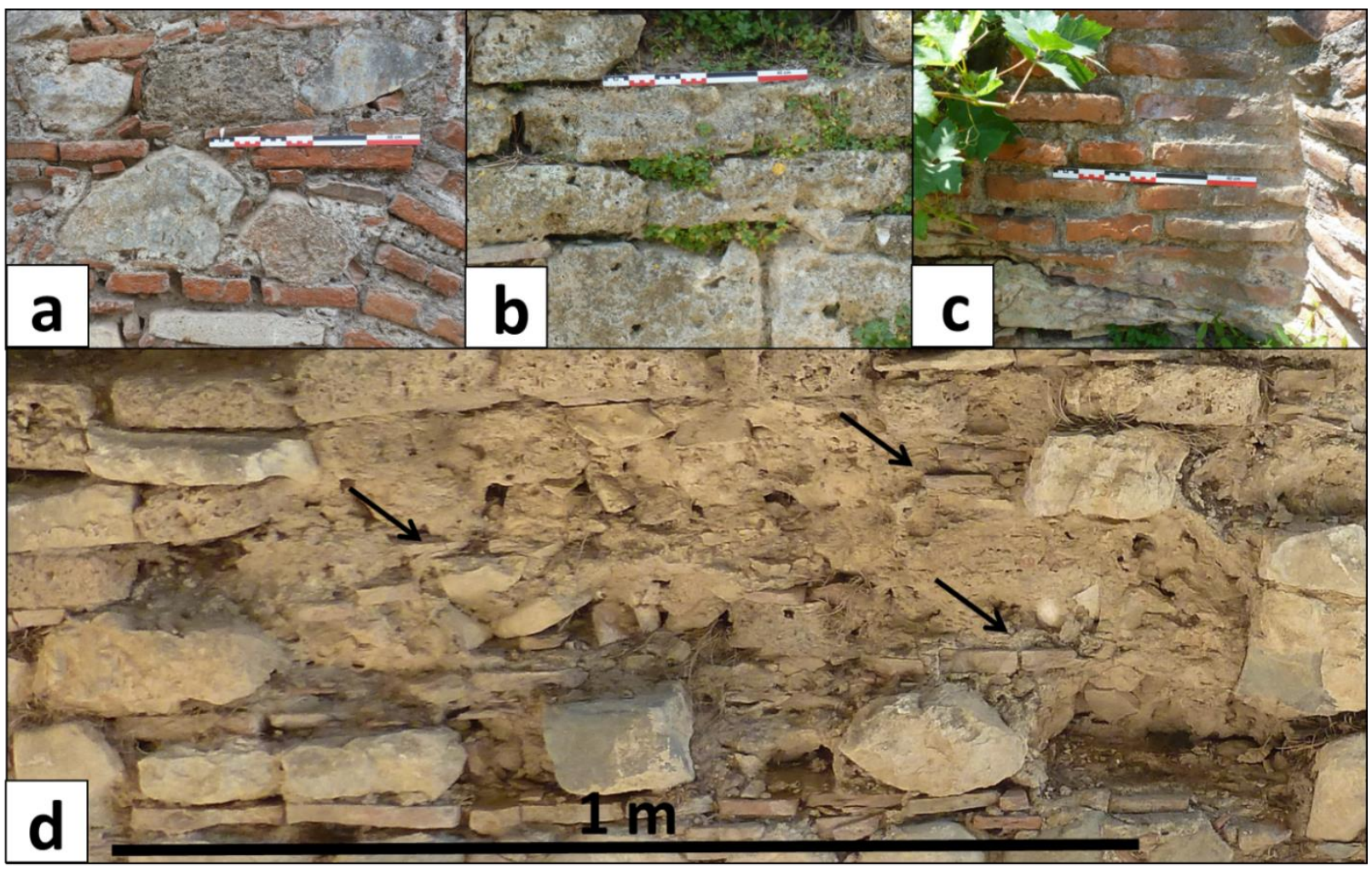

Fig. S1. Detail photos of some construction techniques. (a) Terracottas of MR-0028 close to the city gates, on the left of arch 5. (b) Travertines of MR-0034. (c) Terracottas of the buttress (CF0006). (d) Nucleus of the aqueduct visible under the bridge of Iznik-Orhangazi road, showing alternations of terracottas (arrows) and rubble (MR-0041). 


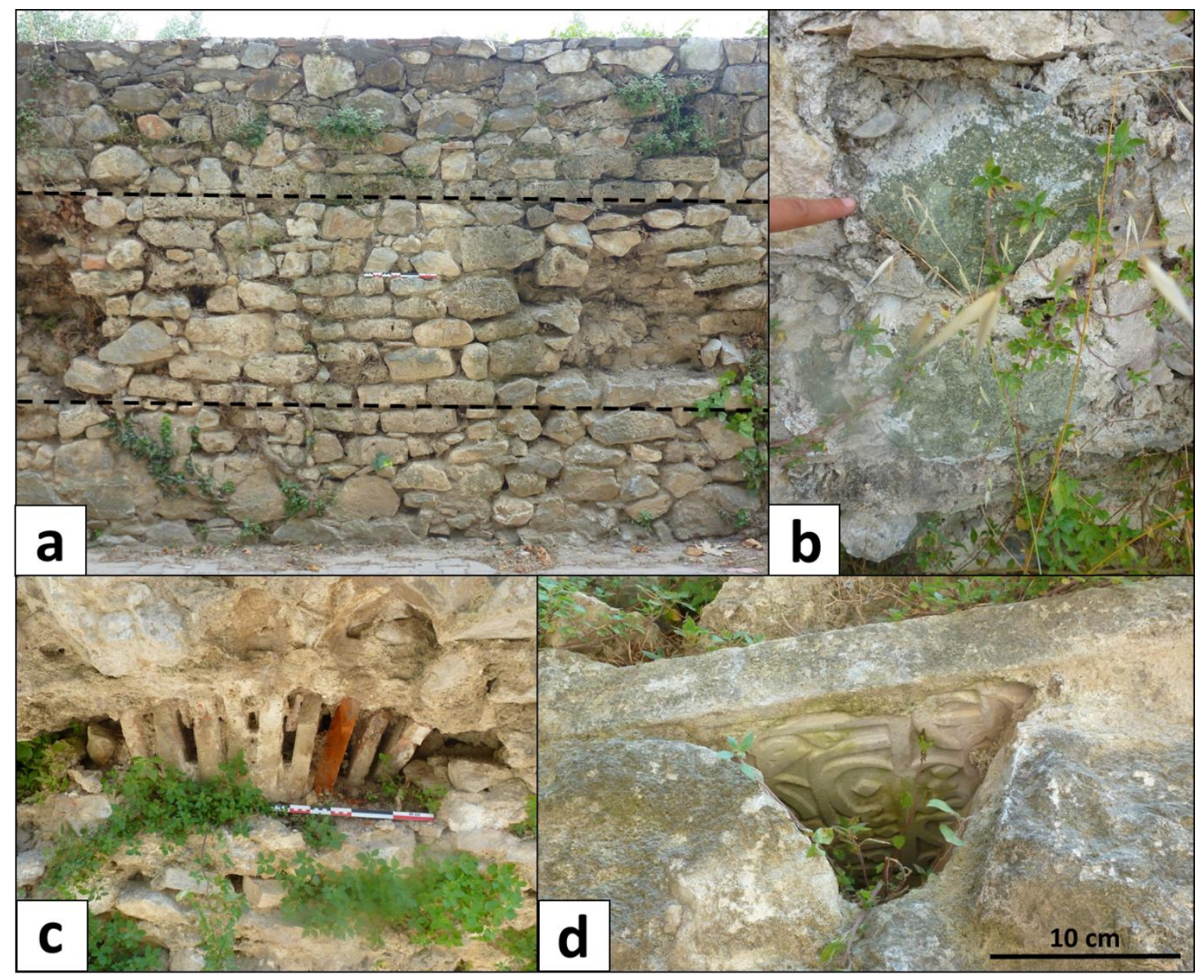

Fig. S2. Detail photos of some construction techniques. (a) Wall built with MR-0036, with two flat levels indicated by broken lines. (b) Green rocks found in MR-0142. (c) Zoomed view on a terracotta arch masked by later rebuildings. (d) Turk gravestone reused in the masonry east of $\operatorname{arch} 8$. 

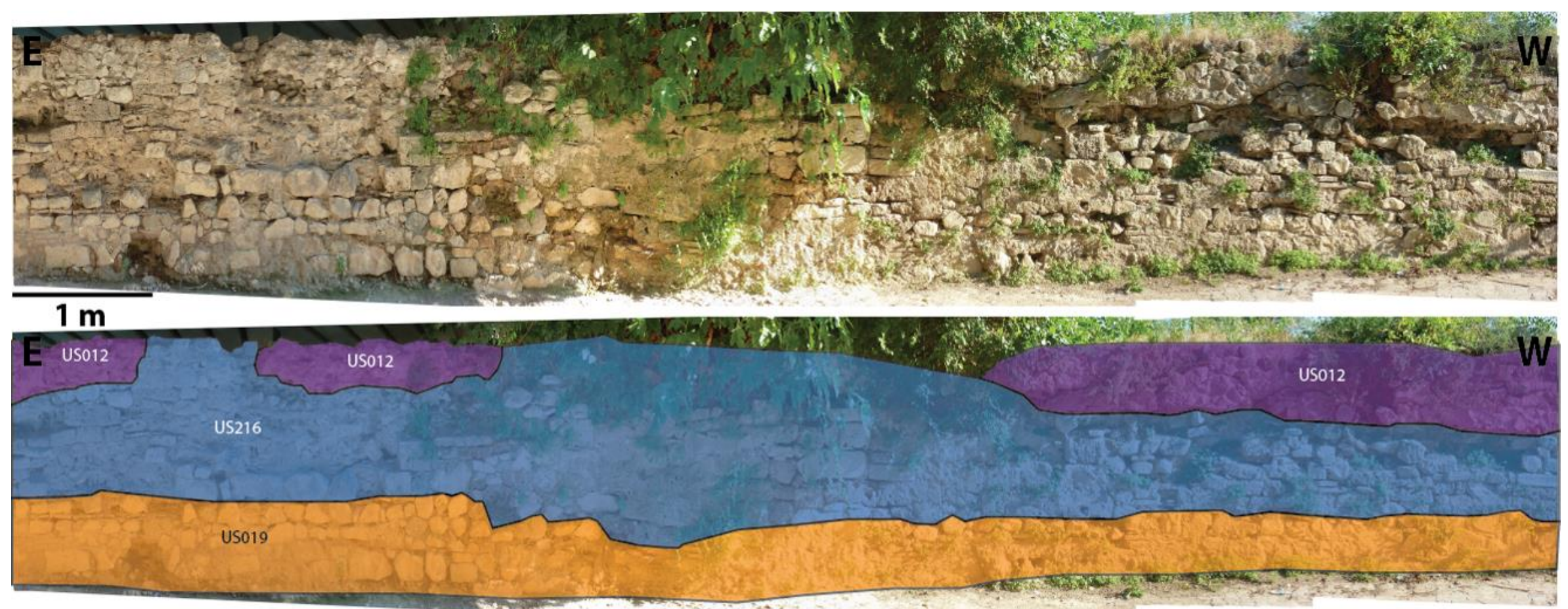

\section{Phase 1 (original construction)}

Phase $3 \mathrm{~b}$ (general rebuilding of the specus)

Phase $6 \mathrm{a}$ (c. $11^{\text {th }}$ century rebuilding)

Fig. S3. Stratigraphy of the section located west of the Iznik-Orhangazi road bridge. The base courses (US019, MR-0041) belong to phase 1. The specus was almost entirely rebuilt in phase 3b (US012, MR-0142). The intermediate courses of the wall's facing (US216, MR-0143) were later added in phase $6 a$. 

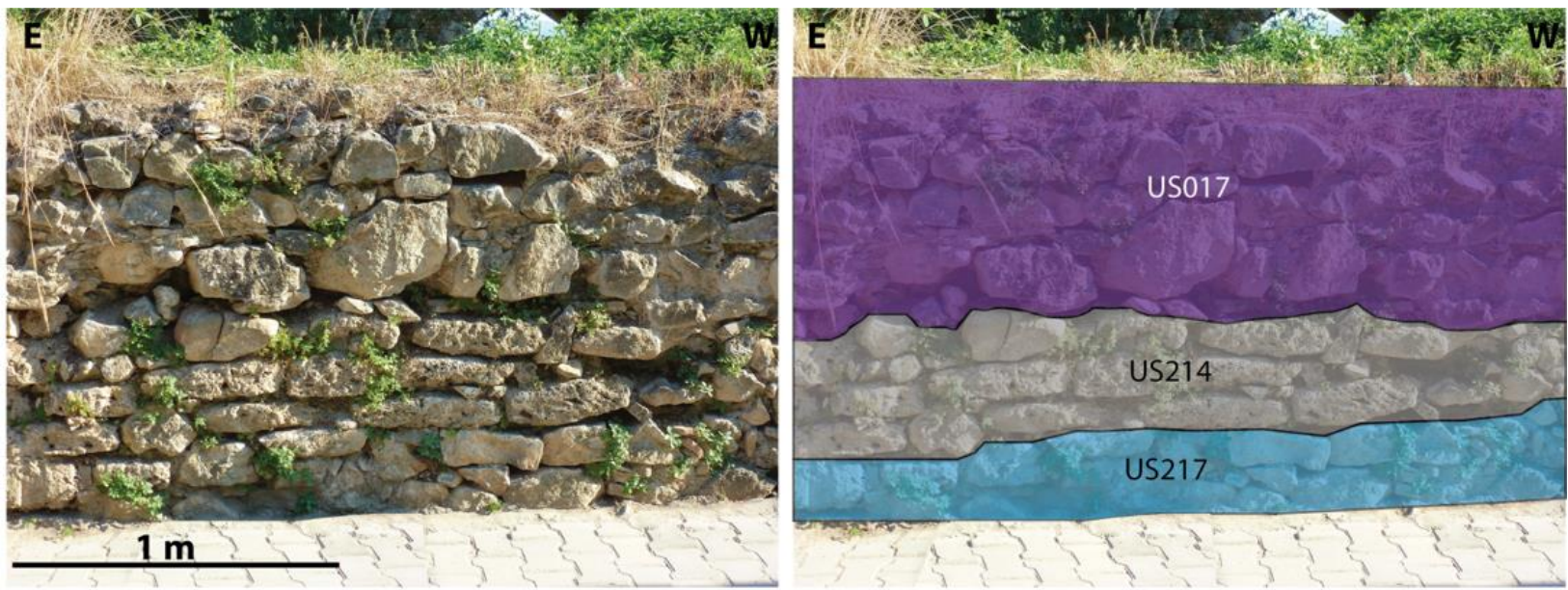

Phase 2 (new limestone rubble facing)

Phase $3 \mathrm{~b}$ (general rebuilding of the specus)

Phase 5 (new travertine facing)

Fig. S4. Stratigraphy of the section located east of Sari Saltuk's tomb, showing from base to top phases 2, 5 and 3b (US217, US214 and US017 respectively).
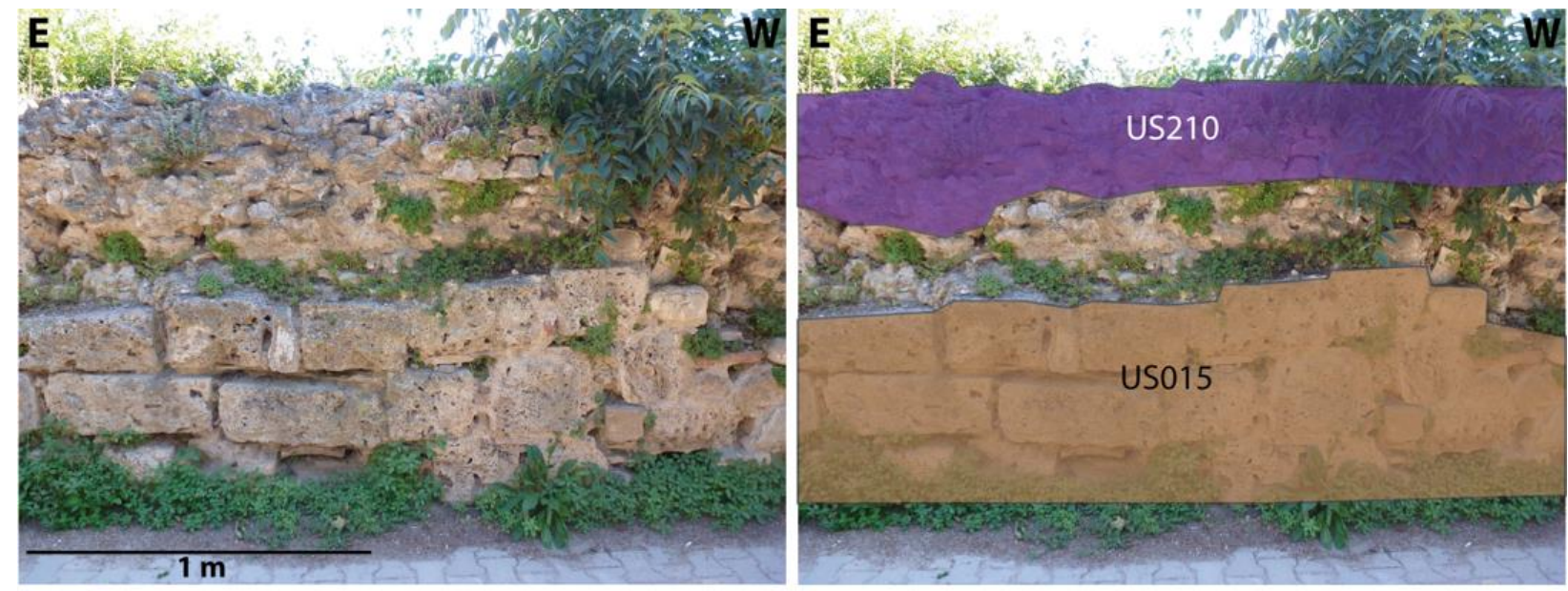

Phase $3 \mathrm{~b}$ (general rebuilding of the specus)

Phase 4 (mixed travertine blocks and terracottas)

Fig. S5. Stratigraphy of the section east of arch 13 , showing the rebuilt specus of phase $3 b$ (US210, MR-0142) and phase 4 at the base (US015, MR-0038). 


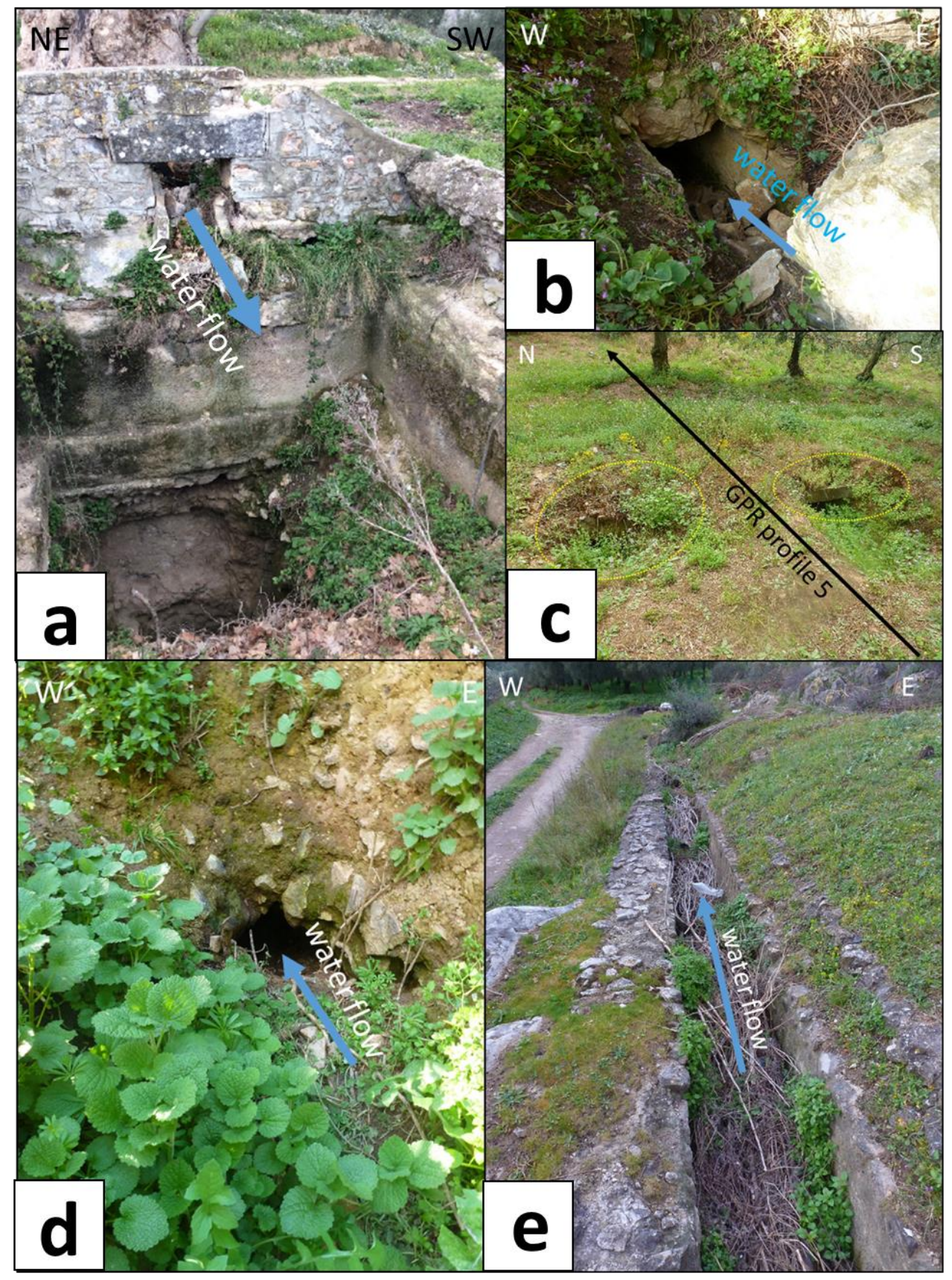

Fig. S6. Field photographs of the aqueduct east of Iznik. (a) Eastern wall of the basin built between the underground and aerial sections of the aqueduct towards the city. (b) Underground channel dug in the carbonate massif. (c) Terracotta structure visible at the eastern end of the underground section. (d) Underground channel made visible by a hole in the ground. (e) The aqueduct upstream of the underground section. 

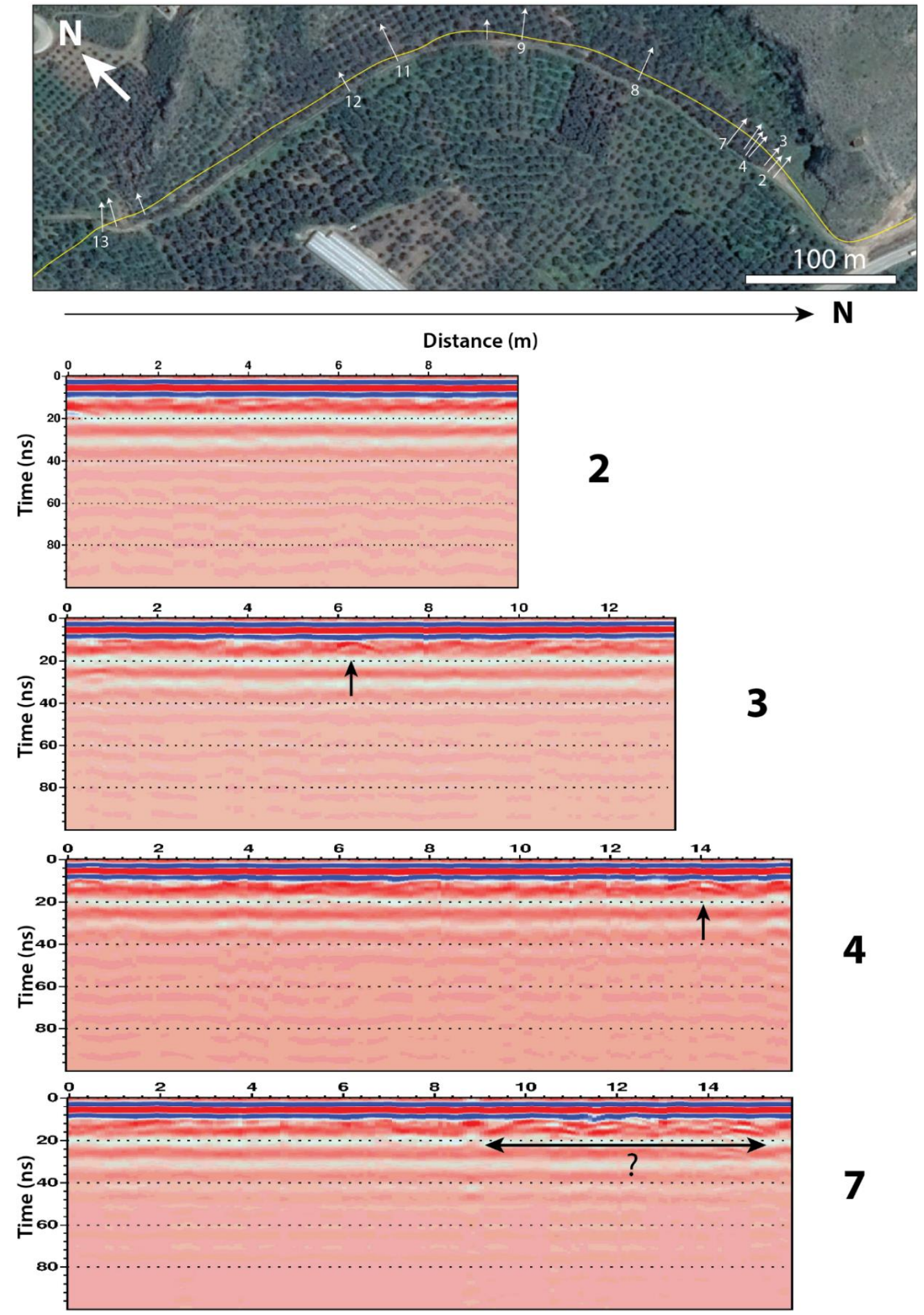

Fig. S7. GPR survey on the underground aqueduct. The map at the top locates the aqueduct's channel in yellow and the transversal GPR acquisitions drawn as white arrows. The numbers correspond to different GPR profiles. At the bottom are shown the GPR images. When possible, visible anomalies compatible with the aqueduct's location are shown in black. 

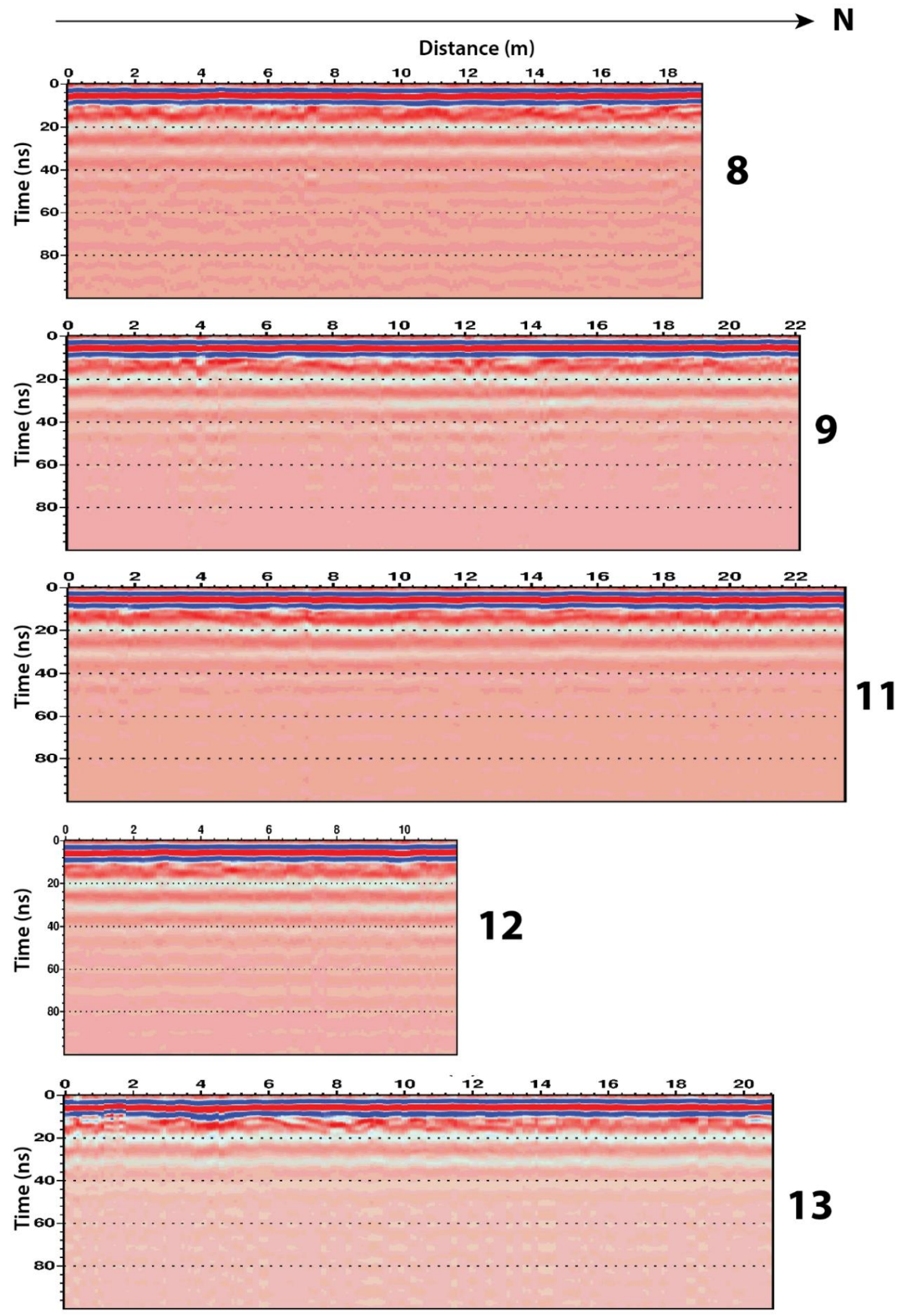

Fig. S8. GPR survey on the underground aqueduct (continued). The numbers correspond to the different GPR profiles located on the previous figure. When possible, visible anomalies compatible with the aqueduct's location are shown in black. 


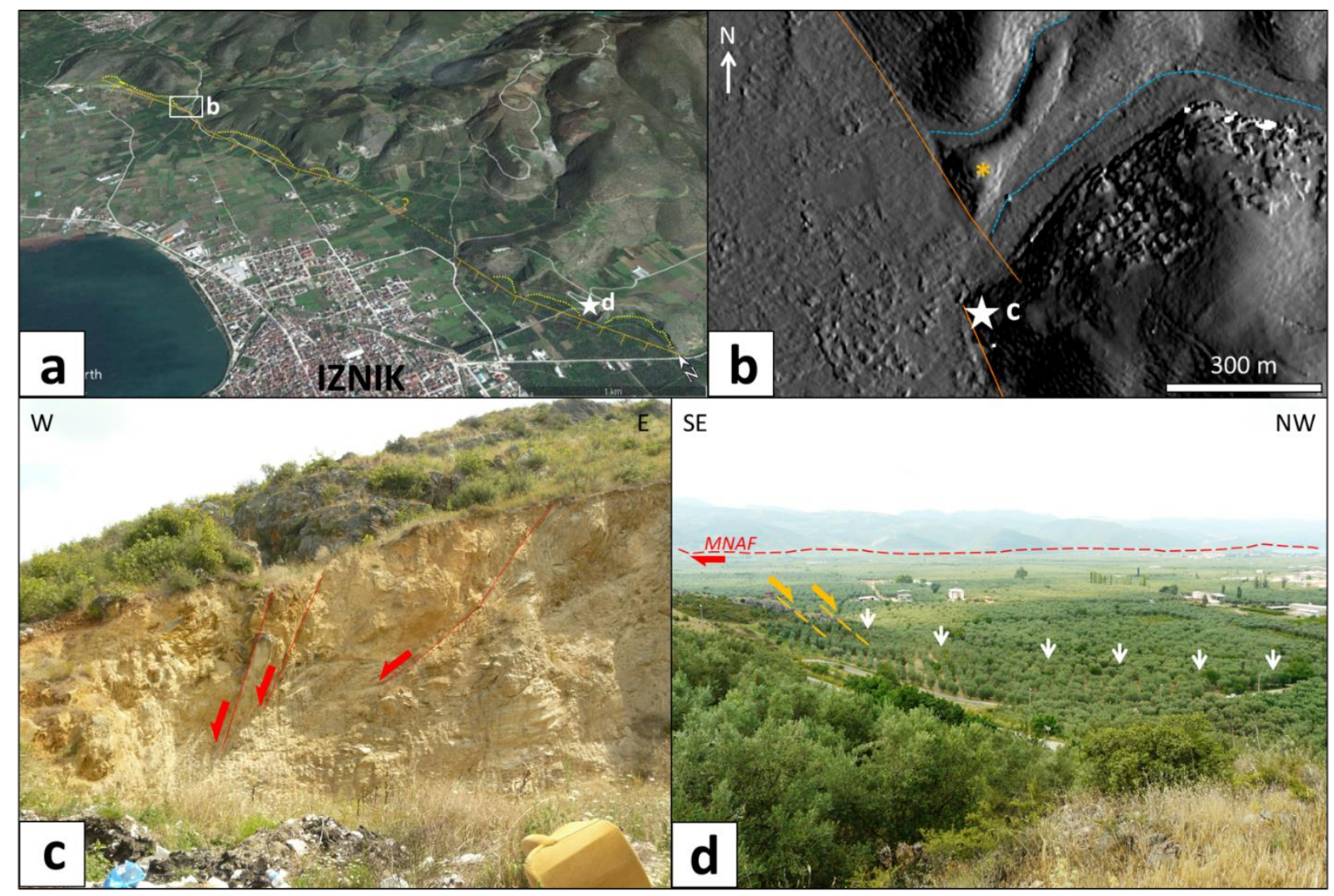

Fig. S9. Morphotectonic evidence of the Elbeyli fault. (a) Satellite view of the Elbeyli fault, drawn in orange. In yellow are drawn spoon-shaped surfaces resulting from the gravitational erosion of the original fault scarp. (b) Shaded Pleiades DEM of the northern part of the fault (drawn in orange). The fault scarp is here interrupted by a large flat valley. The valley on the fault footwall was uplifted and affected by fluvial erosion on its sides (in blue), while the centre made of harder schist rocks was preserved, associated with a small facet (orange asterisk). (c) Outcrop on the footwall showing normal faults in the carbonate rocks, striking N135-150 towards SW. (d) The Elbeyli fault close to Iznik. The photograph was taken on the degraded fault scarp. On the left, the fault (in orange) can be seen cutting and displacing limestone outcrops. The trace of the MNAF (in red) is visible south of Iznik Lake in the background. The path of the aqueduct is located with white arrows. 